Article

\title{
Spatial Pattern of the Seasonal Drought/Burned Area Relationship across Brazilian Biomes: Sensitivity to Drought Metrics and Global Remote-Sensing Fire Products
}

\author{
Joana M. P. Nogueira ${ }^{1}$, Serge Rambal ${ }^{1,2}$, João Paulo R. A. D. Barbosa ${ }^{2}$ and Florent Mouillot ${ }^{1, *}$ \\ 1 UMR CEFE 5175, Centre National de la Recherche Scientifique, Université de Montpellier, \\ Université Paul-Valéry Montpellier, Ecole Pratique des Hautes Etudes, Institut de Recherche pour le \\ Développement, 1919 route de Mende, 34293 Montpellier CEDEX 5, France; \\ joananog@yahoo.com.br (J.M.P.N.); serge.rambal@cefe.cnrs.fr (S.R.) \\ 2 Department of Biology/Plant Physiology, UFLA-Universidade Federal de Lavras, Campus Universitário, \\ Caixa Postal 3037, Lavras CEP 37200-000, MG, Brazil; jp.barbosa@ufla.br \\ * Correspondence: florent.mouillot@ird.fr; Tel.: +33-467-613-292
}

Academic Editors: Valdir Adilson Steinke and Charlei Aparecido da Silva

Received: 15 May 2017; Accepted: 13 June 2017; Published: 16 June 2017

\begin{abstract}
Fires are complex processes having important impacts on biosphere/atmosphere interactions. The spatial and temporal pattern of fire activity is determined by complex feedbacks between climate and plant functioning through and biomass desiccation, usually estimated by fire danger indices (FDI) in official fire risk prevention services. Contrasted vegetation types from fire-prone Brazilian biomes may respond differently to soil water deficit during the fire season. Then, we propose to evaluate the burned area (BA)/FDI relationship across Brazil using most common FDIs and the main BA products from global remote sensing. We computed 12 standard FDIs- at $0.5^{\circ}$ resolution from 2002 to 2011 and used the monthly BA from four BA datasets-from the MODIS sensor (MCD45A1), the MERIS sensor (MERIS FIRE_CCI), the Global Fire Emission Database version 4 (GFED4) and version 4s including small fires (GFED4s). We performed a Principal Component Analysis (PCA) on the coefficients of determination $\left(\mathrm{R}^{2}\right)$ of the FDI/BA relationship to investigate the biome specificities of Brazilian biomes and the sensitivity to BA datasets. Good relationships $\left(R^{2}>0.8\right)$ were observed for all BA datasets, except SPEI $\left(\mathrm{R}^{2}<0.2\right)$. We showed that FDIs computed from empirical water balances considering a lower soil capacity are more correlated to the seasonal pattern of fire occurrence in the Cerrado biome with contrasted adjustments between the western (early drying) and eastern part (late drying), while the fine fuel moisture index is more correlated to the fire seasonal pattern in Amazonia. The biome specificities of the FDI/BA relationship was evaluated with a general linear model. High accuracies in the biome distribution according to the FDI/BA relationship $(>50 \%, p<0.001)$ was observed in Amazonia and Cerrado, with lower accuracy $(<32 \%$, $p<0.001)$ in the Atlantic Forest and Caatinga. These results suggest that the FDI/BA relationship are biome-specific to explain the seasonal course of burned in Brazilian biomes, independently of the global BA product used. Selected FDIs should be used for fire danger forecast in each Brazilian biome.
\end{abstract}

Keywords: fire season; global remote sensing; MCD45A1; GFED; MERIS FIRE_CCI; drought index; fire weather; Brazil

\section{Introduction}

Fire is an abiotic process initiated by natural lightning or human-induced fire settings, and spreads across landscapes, with important consequences on many ecological processes of vegetation 
functioning and dynamic in fire prone biomes [1]. Fire is an intrinsic disturbance of most ecosystems, changing along time the pattern and structure of landscapes. Fire is also used by humans for renewal of grasses and land clearing for intensive agriculture, livestock grazing and logging, altering the species density and composition of communities and releasing trace gases and aerosols into the atmosphere [2]. Therefore, the uncontrolled use and misuse of fires can cause significant impacts on the environment and the human societies [3], altering the landscape as a key resource in developing region [4]. Brazil, among others, is one of the most fire-prone regions globally, mainly in new agricultural frontiers from savannas [5].

Fire occurrence is driven by different constraints [6], where the spatial pattern of weather conditions and fuel resource availability has a key role [7]. It has long ago been emphasized the importance of microclimate (mainly solar radiation, air temperature and relative humidity) effects on fuel load and fuel moisture for flammability of tropical vegetation $[7,8]$, mostly through drought events controlling the seasonality of burned area.

Dryer conditions tend to increase fire activity in non-fuel-limited ecosystems, such as wet forests. In the wet tropical forests (as Amazonia and Atlantic forest in Brazil), the abundant fuel amount as a consequence of a highly productive vegetation is not a limiting factor for fire spread, but are submitted to regular and constant rainfall, limiting the length of the fire season (climate limited) [9]. Climate anomalies as El Niño Southern Oscillation (ENSO) events influence the drought episodes' temporality, and have an additional role on fuel flammability due to depleted soil moisture [10]. Moreover, tropical forests have been recently affected by selective logging or other disturbances, which reduced the canopy cover and modified the microclimate, in turn increasing their susceptibility to initiate fires. The main purpose was to allow for pasture development into forest stands and generate a forest-savanna transition edge, as in the Arc of Deforestation [11]. In contrast, where dryer weather conditions are observed as in grasslands, savannas and xeric shrublands, the growing period preceding the dry season tend to modulate the fire activity by affecting the accumulation of fine fuels $[12,13]$.

Brazilian savannas (or Cerrado) are highly flammable ecosystems with frequent burnings, which mediate the fuel available to burn by reducing tree dominance and the fuel bed continuity of $\mathrm{C} 4$ grasses that allow fire spread [14]. In these ecosystems, the plants are enabled to access the water stored deeply in the soil during the dry season and maintain leaf moisture, transpiration and carbon assimilation [15]. However, Cerrado has experienced rapid land use changes in the last decades as a result of land cleaning for crops and cattle ranching [16]. These changes promote a substitution of the mixed wood/grass ecosystem to shallow-rooted grasslands and consequently a change in the hydrological cycle that influences the local climate and fire season [12]. In turn, at the national scale in Brazil where contrasted vegetation types co-occur, we can expect different seasonal features on fuel moisture, and in turn fire danger.

Estimating fuel moisture content combined with climatic information as wind speed, air relative humidity and temperature, and vegetation types can provide a measure of potential fire risk [17]. Different approaches have been developed to estimate the potential fire risk, using various numerical or qualitative indices in the fire danger rating systems. In general, these indices are non-destructive measures developed to evaluate the fuels stand's proneness to fire in terms of weather conditions, drought hazard or fire behavior. They can be used as proxies to determine the relationship between the predicted daily fire danger and observed fire activity, to choose the most appropriate days to safely reduce fuel loads with controlled burnings [18] or warning signals for populations and fire services.

Drought indices are widely used as guidelines for many fire management activities to assess the fire risk in official warning systems in North America, such as the Canadian Fire Weather Index System [19] and U.S. Fire Danger Rating System [20] and in Europe, as the German Weather Service [21] and the European Forest Fire Risk Forecast System [22]. Among the most used indices in these systems or in experimental studies, we can cite McArthur index (FFDI) [23], Canadian Fire Weather Index (FWI) [19], Swedish Angstrom index (I) [24], Keetch-Bryam Drought Index (KBDI) [20], Russian Nesterov Index (NI) [25], Russian Modified NI (MNI) [26], Zhdanko index (Zh) [27], Australian 
Sharples Fire Weather Index (FMI_KBDI) [28], Standardized Precipitation-Evapotranspiration Index (SPEI) [29] and a simple empirical soil water budget model developed by [30] where soil field capacity is variable.

Many of these indices have been used in fire risk assessment in different vegetation types [31]. However, few efforts have been performed in the regions where fire information is scarce, unreliable or inconsistent [18] such as Brazilian ecosystems. Part of this problem is due to the lack of consistent spatial data in specific areas on vegetation hydrological status and fire occurrence.

A potential alternative to solve this problem is the use of these empirical climate-based fire danger indices, related to fire datasets derived from global remote sensing. Remotely sensed data have been increasingly used as an efficient tool for the monitoring of fire risk from regional to global scales, given the synoptic coverage and repeated temporal sampling [17]. In the last decades, these burned area (BA) datasets have been developed to fire emissions when coupled to land cover information in global models. BA products are derived from different sensors and have been important tools to integrate spatial and temporal fire variability. However, these BAs still present some uncertainties due to different sensors, algorithms and spatial resolutions from which they have been developed [32].

Regarding the panel of available drought indices, uncertainties in global burned area products and the contrasted biome functioning in Brazil, we propose here to identify the spatial distribution of the best drought indicators across Brazil and test their consistency across the global burned products. For this, we: (i) computed the drought/BA relationship by using monthly burned area from MCD45A1, MERIS FIRE CCI, GFED4 and GFED4s datasets and 12 FDIs derived from the gridded daily meteorological CRU-NCEP dataset; (ii) performed a Principal Component Analysis (PCA) on the coefficients of determination $\left(R^{2}\right)$ of the drought/BA relationships; and (iii) tested for any biome specific drought/BA relationship in Amazonia, Cerrado, Caatinga and Atlantic Forest over Brazil during 2002 to 2011 with a general linear model.

\section{Materials and Methods}

\subsection{Study Area}

The study area covers the four main biomes over Brazil (Amazonia, Atlantic Forest, Cerrado and Caatinga) (Figure 1). Brazil extends from $-5.28^{\circ} \mathrm{N}$ to $-33.77^{\circ} \mathrm{S}$ and from $-73.85^{\circ} \mathrm{W}$ to $-34.82^{\circ} \mathrm{W}$, with an area of about 850 million hectares.

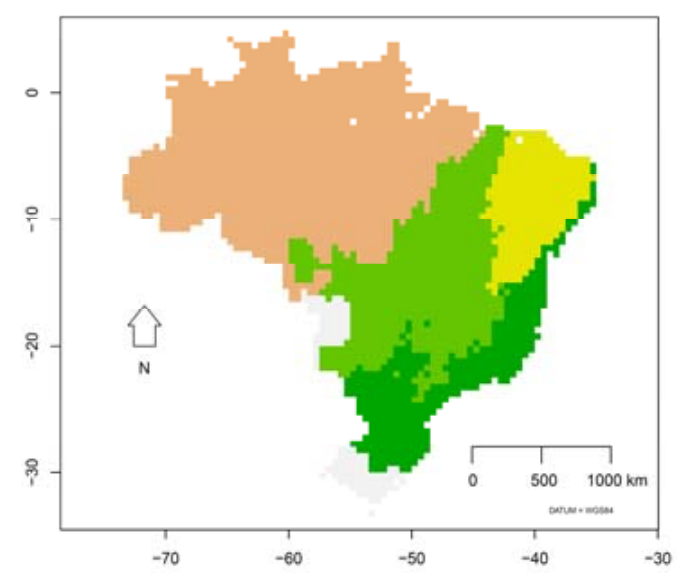

Figure 1. Spatial distribution of the main fire-prone biomes over Brazil. The colors indicate the land cover classification from [5] of each Brazilian biome in according to biomes delimitations from [33]: Tropical/Subtropical Wet Broadleaf Forest (Amazonia, pink), Xeric Shrublands (Caatinga, yellow), Tropical Grasslands, Savannas and Shrublands (Cerrado, light green) and Tropical/Subtropical Dry Broadleaf Forest (Atlantic Forest, dark green) 
Amazonia represents the biggest biome, covering $60 \%$ of the Brazilian territory. In this ecosystem, fire occurrence is usually associated with extreme drought events, as induced by El Niño Southern Oscillation (ENSO) events and with an increasing number of human-induced ignitions due to deforestation, logging activities and expansion of the agriculture frontiers [34]. The climate is typically humid tropical with low seasonal temperature variability and annual precipitations ranging from 1000 to $2000 \mathrm{~mm}$ [35].

The Atlantic Forest extends along the Atlantic coast from the moist and dry broadleaf forest, to grasslands and mangrove forests, with varying climate characteristics. However, more than $90 \%$ of the original vegetation has been deforested since the period of colonization and is still affected by urban growth and agricultural expansion [36]. As a result of this long history of disturbance, the Atlantic forest is composed of few large patches with native forests and recent small and numerous patches of managed plantations (i.e., Pinus sp., Eucalyptus sp.), and cropland and pastures. The fire activity in this biome is generally human-induced from logging activities that increase the amount of debris on the forest floor, leading this biome to be susceptible to fires and vulnerable to secondary fires [36].

Cerrado is a mosaic of grasslands, open shrublands and woodlands, with different tree cover gradients which cover $22 \%$ of the Brazilian territory with altitude ranging $300 \mathrm{~m}$ to $1000 \mathrm{~m}$ above sea level [37]. The climate is seasonally tropical with annual average precipitations varying between 1200 and $1800 \mathrm{~mm}$ with dry winters. The fire is an intrinsic recurrent disturbance in this biome, currently more used for land clearing and agricultural activities, renewal of pastures mainly to promote fresh grass growing during the dry season, from end of July to September [9].

Caatinga is the northeast portion of the country covering about $10 \%$ of the Brazilian territory. This biome is annually marked by high temperatures with low monthly variability, high severe drought and low relative air humidity. The rainy season only happens in summer (January and February) but the annual precipitation amount is low with less than $700 \mathrm{~mm}$. Therefore, the predominant vegetation is xerophytic with deciduous trees and scrubland species, mainly Cactaceae and Bromeliaceae. Due to low vegetation productivity in the rainy season, fire is not extensively used for pasture improvements in this biome. Thus, fire is mostly used for land clearing after cutting of existing vegetation [38].

\subsection{Land Cover Dataset}

We used the spatial distribution and composition of the main land cover over Brazil from the fuelbed vegetation map from [5]. This dataset is built on the fuel characteristics using the Fuel Characteristics Classification System v2.2 [39], which considers the structural and geographic diversity in wildland fuels into six strata (trees, shrubs, grasses, woody surface fuels, litter and soil organic matter) and includes them in fuelbelds according to their physical and chemical properties. This fuelbed map is adapted to climate and vegetation differences using the Globcover v2.2 land cover product [40] from 2004 to 2006 at $300 \mathrm{~m}$ spatial resolution and biome classification from terrestrial ecoregions map [41]. We rescaled this map at $0.5^{\circ}$ spatial resolution. Thus, the land cover classification from fuelbed maps of Tropical/Subtropical Wet Broadleaf Forest, Tropical/Subtropical Dry Broadleaf Forest, Tropical/Temperate Grasslands, Savannas and Shrublands and Desert/Xeric Shrublands fuelbelds correspond respectively to Amazonia, Atlantic Forest, Cerrado and Caatinga vegetation over Brazil.

\subsection{Climate Data}

We used the daily gridded meteorological variables compiled in the CRU-NCEP dataset (available at [42] which uses more reliable precipitation data at $0.5^{\circ}$ spatial resolution from CRU TS Version 3.2 (Climatic Research Unit Time Series) dataset [43] combined with a high daily temporal resolution from NCEP reanalysis product [44] at $2.5^{\circ} \times 2.5^{\circ}$ spatial resolution. The CRU-NCEP Version 5.3 is registered in global file (NetCDF format) for each climate available at six hours temporal resolution and $0.5^{\circ}$ spatial resolution. We used daily mean incoming short wave solar radiation $\left(\mathrm{Rg}, \mathrm{W} \cdot \mathrm{m}^{-2}\right)$, air relative humidity $\left(\mathrm{q}_{\text {air }}, \mathrm{g} \cdot \mathrm{g}^{-1}\right)$, air pressure (press, $\mathrm{Pa}$ ), horizontal and vertical wind components 
( $\mathrm{u}$ and $\mathrm{w}$ wind, $\mathrm{m} \cdot \mathrm{s}^{-1}$ ), total precipitation (Prec, $\mathrm{mm}$ ) and air temperature $\left(\mathrm{T}_{\mathrm{air}}, \mathrm{K}\right.$ ) from 2002 to 2011 to calculate the daily variables required for fire danger indices (FDI). All equations are described in Table A1. CRU-monthly rainfall data have been demonstrated to be well correlated to the local Brazil dataset over 1980-2013. The median correlation values for the grid-cells over Brazil are 0.67 [45].

\subsection{Meteorological Fire Danger Indices (FDI)}

We calculated 11 FDIs according to equations synthesized in (Table A2). Some of the drought indices are used as stand-alone indices directly related to fire potential, while some others are included as sub-models in more integrated rating systems such as the Canadian Forest Fire Weather Index (FWI) and the McArthur's Forest Fire Danger Index.

The Keetch-Byram drought index (KBDI) is a cumulative estimate of water-limitation in upper soil layers and surface litter. It requires only few meteorological data: maximum daily temperature, total daily precipitation and the normal (mean annual) precipitation. KBDI is initialized when the soil is at field capacity $=200 \mathrm{~mm}$. It has been successfully applied in tropical climates [46].

The Australian McArthur Forest Fire Danger Index (FFDI) is a function of air relative humidity, maximum temperature, average wind velocity and a drought factor (D) [23]. $D$ varies between 0 and 10 to represent the influence of recent temperatures and rainfall events on fuel availability based on the soil moisture deficit, which is commonly calculated with the KBDI [47] during the time since last rain $(\mathrm{N}$, days) and the amount of precipitation $(\mathrm{mm})$.

The Fire Weather Index (FWI) [19] uses the daily temperatures, wind speed, daily accumulative precipitation and relative air humidity to estimate the fuel moisture content in different compartments of the vegetation and the subsequent fire danger [48]. The fuel moisture components include the Fine Fuel Moisture Code (FFMC) as a proxy for the litter and fine fuels moisture; the Duff Moisture Code (DMC) for fuel moisture in the duff layer and woody medium-size fuels; and the Drought Code (DC) for fuel moisture in the organic deep layers. The combination of DMC and DC is usually related to the total amount of fuel available for combustion.

The Australian Sharples Fire Weather Index (FMI) is based on Viney's model [49] for assessing the moisture content of fine and dead fuels. This index considers the air temperature, relative air humidity and a drought factor (commonly the KBDI index) to evaluate the effects of fuel availability [28]. The Angstrom index (I) considers air temperature and relative humidity to simulate the daily air dryness. The values of I below 2.0 indicate weather conditions very likely for fire events while values above 4.0 indicate unfavorable conditions [24]. The Zhdanko index ( $\mathrm{Zh}$ ) considers the N, K, and dew point deficit, which is the difference among the dew point and mid-day temperature [27].

The Nesterov index (NI) uses the mid-day and dew-point temperature and the number of days since the last rainfall event above $3 \mathrm{~mm}$. Daily drought indices are cumulated as long as no rainfall event above $3 \mathrm{~mm}$ happens, so the index has no fixed upper limit [25]. Rainfall events above $3 \mathrm{~mm}$ reset the index to zero. The values below 300 usually indicate the days with minimal fire potential, while the fire potential is predictable and mostly predictable above 1000 and 10,000, respectively. The Modified Nesterov Index (MNI) is similar to NI, but with the additional variable (K) controlling the resetting value when a rainfall event happens. $K$ is a scale coefficient varying between 0 and 1 so that this reduction factor is equal to 1 when no rainfall occurs (MNI not affected), and is equal to 0 when daily rainfall is above $20 \mathrm{~mm}$ (MNI rest to 0 as in NI), but $\mathrm{K}$ gradually decreases between these thresholds according to the rainfall amount [26].

Standardized Precipitation Evapotranspiration Index (SPEI) is a drought index that quantifies how it deviates from a baseline water balance, wetter or dryer [50]. The SPEI is an over-simple water budget, calculating water deficit $D$ as the difference between precipitation $(P)$ and potential evapotranspiration $(P E T)$ on a monthly time step i.e., $D=P-P E T$. Different SPEIs are obtained for contrasted time-scales ranging from representing the water balance summed over the previous $k$ months

$$
D_{n}^{k}=\sum_{i=0}^{k-1}\left(P_{n-i}-P E T_{n-i}\right)
$$


where $k$ in month is the time windows of the aggregation and $n$ is the considered month. A log-logistic probability distribution function is fitted to $D$. SPEI data are provided by the Global SPEI database vs. 2.4 [51].

The Linacre water-limitation index (LINACRE) is derived from a soil water budget simulated on a daily time step by using a bucket-type model with a limited storage capacity. The LINACRE is mathematically represented by a difference equation in which the daily change in soil water storage equals rain input $(P)$ minus outputs which are deep drainage $(D r)$ and actual evaporation $(A E T)$. The water stored in the soil $(S)$ is up bounded by the field capacity $(F C)$. When $S$ exceeds the $F C$ threshold, extra water flows down as deep drainage. AET extracts water from the soil compartment. $A E T$ is a fraction of potential evaporation (PET) both related to $S$ and to PET. For reducing PET to AET, Linacre [30] proposed a simplified algorithm: AET rate equals whichever is less, PET or AETmax. $(\mathrm{S} / \mathrm{FC})^{2}$. Finally, the model may be summarized by two coupled equations:

$$
\begin{aligned}
& A E T=\min \left[A E T_{\max }\left(\frac{S}{F C}\right)^{2}, P E T\right] \\
& S(t+1)=\min [S(t)+P-A E T, F C]
\end{aligned}
$$

For Brazil, $A E T_{\max }$ has been fixed to $5 \mathrm{~mm}[52,53]$. We used 4 contrasted soil retention properties: $100,250,550$ and $750 \mathrm{~mm}$ corresponding to vegetation covers ranging short grassland or shrubland with shallow roots to dense forests or woodlands with deeper root systems.

All indices were calculated on a daily time step according to their original formulas, using the climate CRU-NCEP dataset described above at $0.5^{\circ}$ spatial resolution from 2002 to 2011 (Figure 2). All daily values were then averaged on a monthly time step. Only FWI components and SPEI in different time-scales were computed, respectively, by functions developed in fwi.fbp library [54] from $\mathrm{R}$ cran program [55] and the monthly data available in SPEI database [51], which covers the global frequency of SPEI at scales from 1 to 48 months at $0.5^{\circ}$ gridded spatial resolution [56], using the same CRU-NCEP climate variables. In this SPEI database, the reference period for the calculation corresponds to the whole study. In addition, we tested the SPEI time-windows of 1, 3, 9, 12, 24 and 48 months.

\subsection{Burned Area Datasets}

We used four monthly global burned area (BA) datasets (MCD45A1, GFED4, GFED4s and MERIS FIRE_CCI v4.1) (Table 1) which are based on different sensors derived from remote sensing images from 2002 to 2011 and at $0.5^{\circ}$ spatial resolution. The MCD45A1 dataset is a gridded data that provides the monthly burned area $\left(\mathrm{km}^{2}\right)$ generated by a multi-phase algorithm based on bi-directional reflectance change detection approach [57]. The Collection 5 Level 3 dataset used in this study is available in NetCDF format files from 2000 to present. The fourth generation of the Global Fire Emissions Database (GFED4) [58] version 4.1 is available as monthly burned area (ha) layers in separate HDF4 Scientific Data Set (SDS) file format since 1995. We also used an updated version of GFED4 v4.1, which provide monthly BA boosted with small fires based on upon scaling active fire counts (GFED4s) [59]. This dataset is organized as annual files with four layers in the HDF5 format, from which we used the first layer providing the fraction of each grid cell burned in that month. The MERIS FIRE_CCI v4.1 is a recently BA grid dataset [60] delivered from the ESA Fire Cci project [61] and generated by an algorithm based on processing in two-phase [62]. The MERIS FIRE_CCI v4.1 provides monthly burned area $\left(\mathrm{m}^{2}\right)$ in NetCDF format files from 2002 to 2011 and is a dataset validated from multi-temporal pairs of Landsat images sites with stratified random sample [63]. 

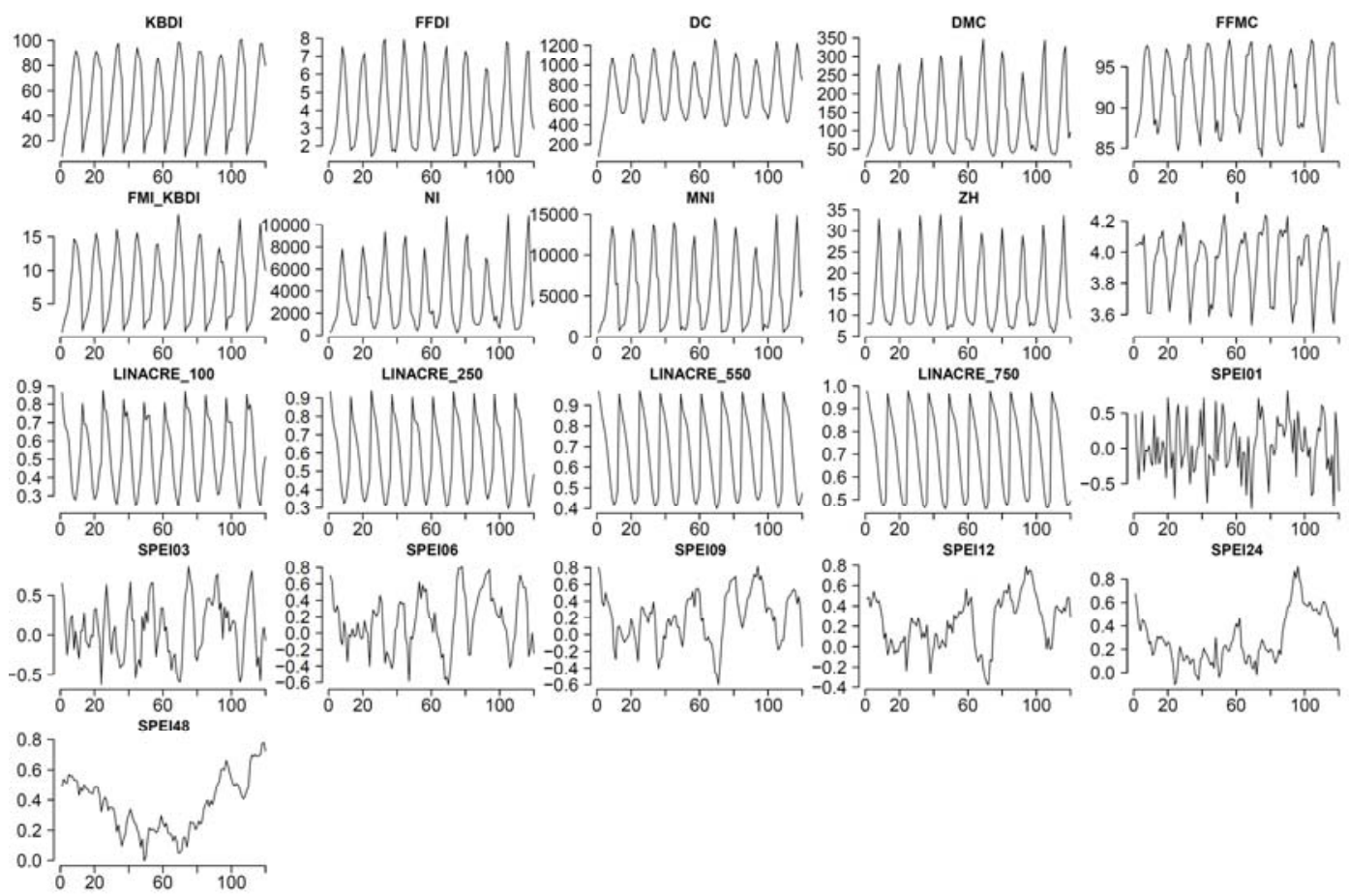

Figure 2. Monthly average of meteorological fire danger indices computed from the CRU-NCEP dataset at $0.5^{\circ}$ spatial resolution from 2002 to 2011. The graphs represent the Keetch-Bryam Drought Index (KBDI), McArthur index (FFDI), Drought Code (DC), Duff Moisture Code (DMC), Fine Fuel Moisture Code (FFMC), Australian Sharples Fire Weather Index (FMI_KBDI), Russian Nesterov Index (NI), Russian Modified NI (MNI), Zhdanko index (Zh), Swedish Angstrom index (I), Linacre index with 100, 250, 550 and $750 \mathrm{~mm}$ of field soil capacity (Linacre_100-750), and the monthly Standard Precipitation Evapotranspiration index SPEI computed for the time windows 1, 3, 6, 9, 12, 24 and 48 months.

Table 1. Overview of global burned area products (BA).

\begin{tabular}{ccccc}
\hline BA Products & Satellite/Sensor & $\begin{array}{c}\text { Temporal and } \\
\text { Spatial Resolution }\end{array}$ & Server Download & References \\
\hline MCD45A1 & $\begin{array}{c}\text { MODIS/Terra and } \\
\text { Aqua }\end{array}$ & daily, 0.5 & {$[64]$} & {$[57]$} \\
GFED4 & $\begin{array}{c}\text { TRMM, VIRS, } \\
\text { ATSR } \\
\text { TRMM, VIRS, } \\
\text { GFED4s }\end{array}$ & monthly, 0.25 & {$[58]$} \\
MODIS/Terra & [65] & {$[59]$} \\
\hline $\begin{array}{c}\text { MERIS FIRE_CCI } \\
\text { v4.1 }\end{array}$ & $\begin{array}{c}\text { MERIS/Envisat } \\
\text { and MODIS }\end{array}$ & monthly, 0.5 & {$[61]$} & {$[60,62]$} \\
\hline
\end{tabular}

MODIS = MODerate resolution Imaging Spectroradiometer; TRMM = Tropical Rainfall Measuring Mission; VIRS = Visible and Infrared Scanner; ATSR = Along-Track Scanning radiometer; MERIS = MEdium Resolution Imaging Spectrometer.

For this study, we rescaled GFED4 and GFED4s datasets to $0.5^{\circ}$ spatial resolution monthly from 2002 to 2011 and analyzed in $\mathrm{km}^{2}$ with lat/long cartographic projection and datum WGS84.

\subsection{Data Analysis}

As a first step, we evaluated the linear relationship between the monthly values of each meteorological fire danger index (FDI) and the monthly burned area (BA) information from the 
different BA datasets, using the coefficient of determination $\left(\mathrm{R}^{2}\right)$ for each grid cell (i). In a second step, we performed a Principal Component Analysis (PCA) (ii), where individuals are grid cells, and variables are the $\mathrm{R}^{2}$ values obtained from the monthly FDI/BA relationships. From this analysis, we could obtain for each grid cell, its value on each PCA axis, as well as the main FDIs contributing to these axes. To assess whether the FDI/BA relationships were biome specific, we then computed a biome-specific approach using a general linear model (GLM, Equation (1)) (iii), where the dependent variable represent the biome map, and explanatory variables are the PCA axis 1,2 and 3. All analyses were performed in the $\mathrm{R}$ cran program and the methodological steps are described in Figure 3.

$$
\mathrm{VEG}=\mathrm{aPC} 1+\mathrm{bPC} 2+\mathrm{cPC} 3+\varepsilon
$$

where VEG indicate the vegetal type; PC 1-3 the axes from 1 to 3 from principal components analysis; and $\mathrm{a}, \mathrm{b}, \mathrm{c}$ are the slopes of linear regressions and $\varepsilon$ is the error.

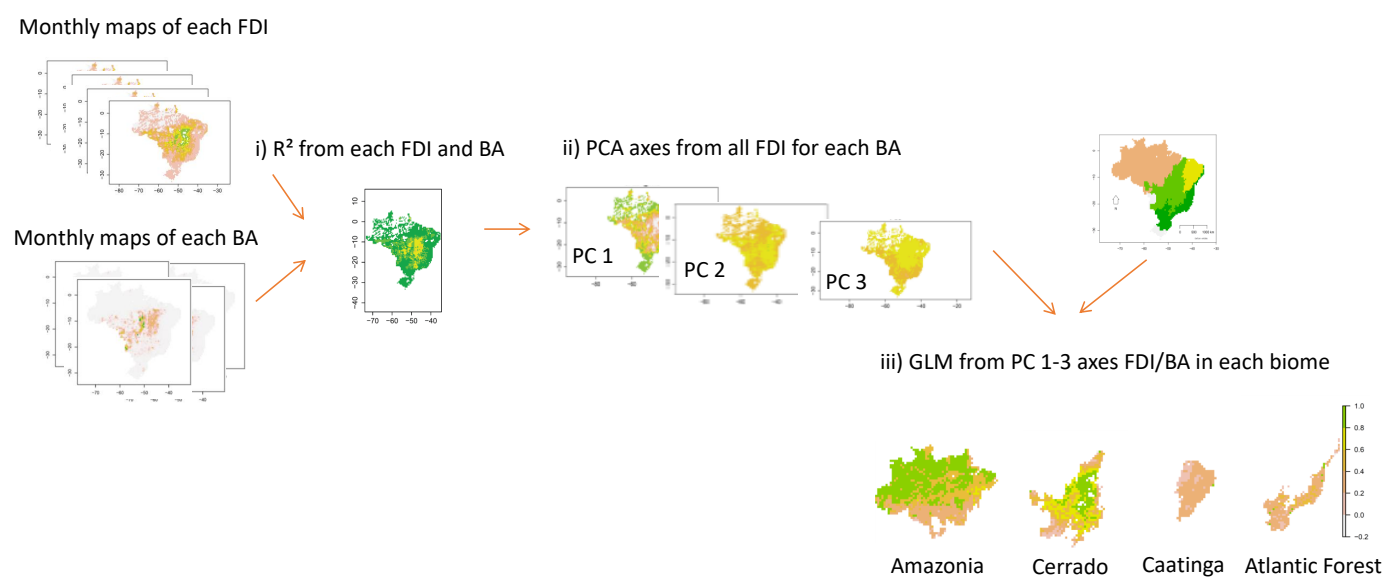

Figure 3. Flowchart of analytical steps used in this study. In (i), the monthly values of each meteorological fire danger index (FDI) were compared with monthly burned area (BA) information from the BA datasets, using the coefficient of determination $\left(R^{2}\right)$ for each grid cell (ii). Then, from this monthly FDI/BA relationship represented by $\mathrm{R}^{2}$ maps, we performed a Principal Component Analysis (PCA) (ii), where we could obtain for each grid cell, the main FDIs contributing to these axes. To assess whether the FDI/BA relationships were biome specific, we then computed a biome-specific approach using a general linear model (GLM) (iii), where the dependent variable represent the biome map, and explanatory variables are the PCA axis 1,2 and 3.

\section{Results}

\subsection{Performance of Fire Danger Indices to the Seasonal Variation of BA from Global Remote Sensing Datasets}

All FDIs showed good correlations $\left(R^{2}\right)$ with BA for all datasets, except for SPEIs $\left(R^{2}<0.2\right)$. The highest $R^{2}$ values were found mainly in the central region of Brazil $\left(R^{2}>0.8\right)$, a consistent result for all BA datasets (MCD45A1, GFED4, MERIS FIRE_CCI and GFED4s) (Figure A1a-d). Better correlations however could be observed for GFED4s including small fires outside this central region.

To figure out which FDIs had a better correlation for each grid cell and assemble the grid cells with similar FDI/BA relationship, we performed a PCA on all the FDI/BA R $^{2}$. The three first principal components (PC 1-3) showed an overall explained variance higher than $95 \%$ for all BA datasets. PCA coordinates higher than 0.5 for axis 1 were found on the southern, northeastern and northern regions of Brazil, while PCA1 axis values were lower than -0.5 for the central region for all BA datasets (Figure 4). 


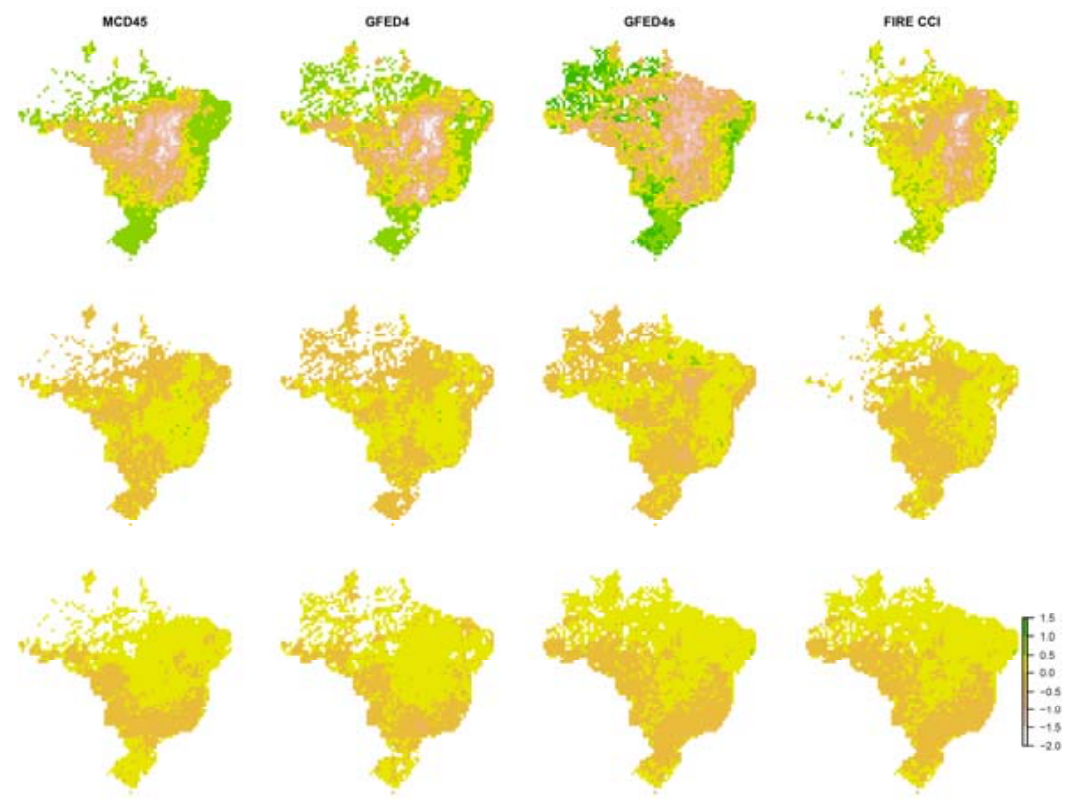

Figure 4. Maps of eigenvectors from three principal components axes (PC 1-3, from top to bottom) from Principal Components Analyses (PCA) to each burned area (BA) datasets (MCD45, GFED4, GFED4s and MERIS FIRE_CCI). The PCA was performed from coefficient of determination $\left(\mathrm{R}^{2}\right)$ between BA and all fire meteorological danger indices (FDI) computed from satellite climate dataset (CRU-NCEP) at $0.5^{\circ}$ of spatial resolution from 2002 to 2011. The FDIs are McArthur index (FFDI), Duff Moisture Code (DMC), Drought Code (DC), Fine Fuel Moisture Code (FFMC), Swedish Angstrom index (I), Keetch-Bryam Drought Index (KBDI), Russian Nesterov Index (NI), Russian Modified NI (MNI), Standardized Precipitation-Evapotranspiration Index (SPEI) from 1 to 48 months of drought (SPEI 1-48), Zhdanko index (Zh), Australian Sharples Fire Weather Index (FMI_KBDI) and Linacre index with 100, 250, 550 and 750 mm of field soil capacity (Linacre_100-750).

When looking at the variable map (Figure 5) for this PCA1 axis, negative values correspond to the highest correlations between FDIs and BA, except Linacre indices for soil field capacities $550 \mathrm{~mm}$ and $750 \mathrm{~mm}$, illustrating that the seasonal BA in the central region is highly correlated to most of the drought indices, while other regions are the less correlated. Regarding PCA axis 2, positive values were observed for the eastern central region and the north, while negative values were observed mostly for the southern and western regions. The PCA map of contributing variables (Figure 5) illustrates here the high correlation of BA with Linacre indices for deep soils with a delayed drought onset on positive values of the PCA2 axis, while other regions would be more correlated to FFMC and ZH indices characterized by an early drought onset. In conclusion, the main seasonal BA pattern is the best represented by surface fuel moisture FFDI and Linacre 100 in the Cerrado biome, with an earlier adjustment on the western part (PCA2 negative driven by FFMC) and a delayed adjustment on the eastern part (PCA2 positive influence by Linacre 550-750). In Amazonia, the seasonal pattern is less correlated with FFDI and Linacre_100, but more influenced by the early-drying FFMC. 

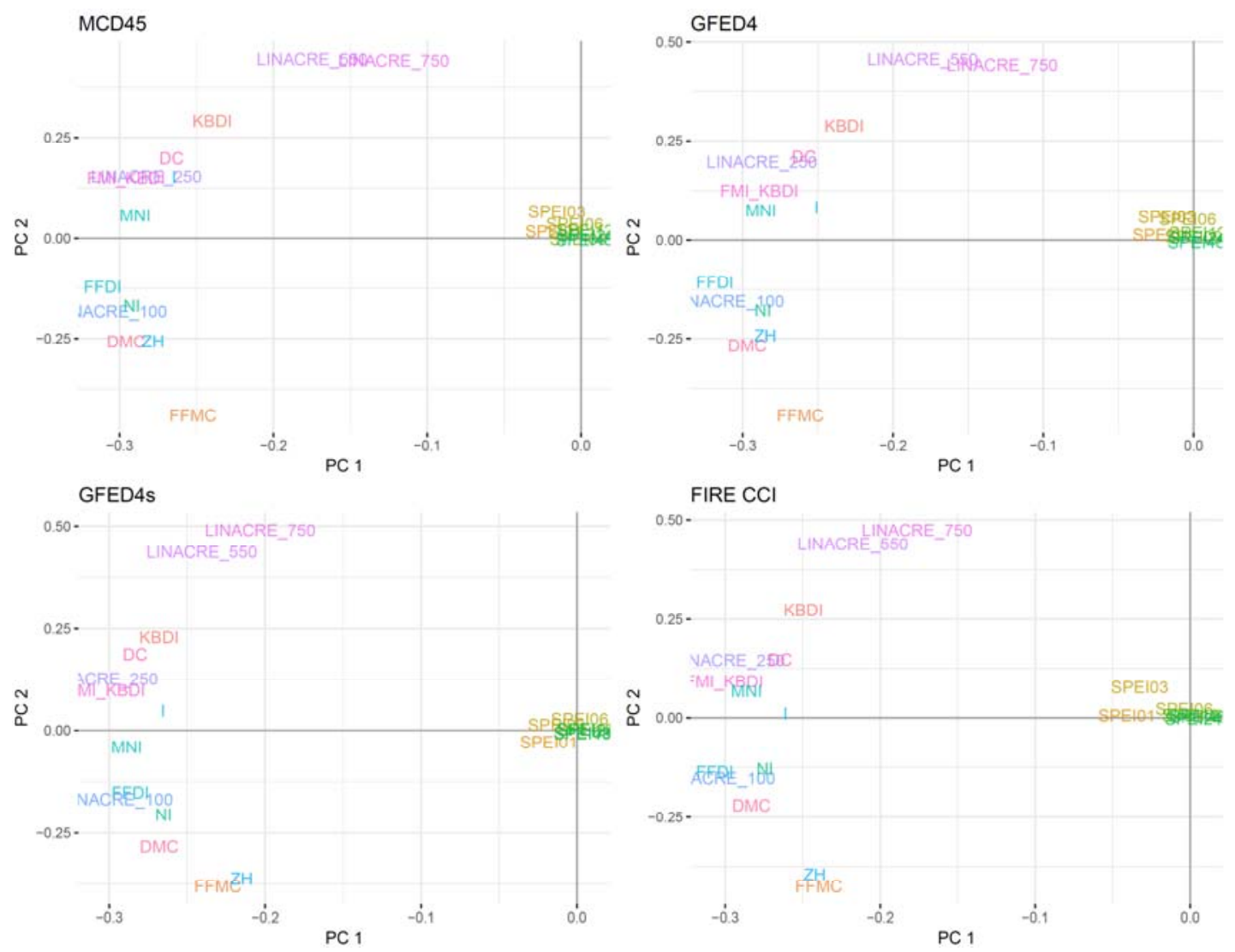

Figure 5. Eigenvalues from two first principal components axes (PC 1 and PC 2) for each burned area datasets (MCD45, GFED4, GFED4s and MERIS FIRE_CCI) and all fire meteorological danger indices (FDI) computed from climate dataset (CRU-NCEP) at $0.5^{\circ}$ of spatial resolution from 2002 to 2011 . The FDI evaluated are McArthur index (FFDI), Duff Moisture Code (DMC), Drought Code (DC), Fine Fuel Moisture Code (FFMC), Swedish Angstrom index (I), Keetch-Bryam Drought Index (KBDI), Russian Nesterov Index (NI), Russian Modified NI (MNI), Standardized Precipitation-Evapotranspiration Index (SPEI) from 1 to 48 months of drought (SPEI 1-48), Zhdanko index (Zh), Australian Sharples Fire Weather Index (FMI_KBDI) and Linacre index with 100, 250, 550 and $750 \mathrm{~mm}$ of field soil capacity (Linacre_100-750).

\subsection{Biome Specific FDI/BA Relationship}

Results from the GLM distribution of biomes from PCA axis performed on the FDI/BA relationships are presented in Figure 6. They represent how the seasonal FDI/BA relationships are specific to the selected biomes. In general, the GLM with the three first main principal component axes showed high probabilities $(>50 \%)$ to accurately predict the biome distribution of Amazonia and Cerrado with no major discrepancies between BA datasets. Lower prediction probabilities $(<32 \%)$ were however observed in the Atlantic Forest and Caatinga. For Amazonia and Cerrado, these results exhibited higher probabilities for BA products MCD45 (70\%), MERIS FIRE_CCI (69\%) and GFED4 $(63 \%)$ than the BA product including small fires GFED4s (53\%). In the Atlantic Forest, the MERIS FIRE_CCI dataset showed higher values (31\%) than other BA datasets. All BA datasets showed low probabilities in the Caatinga (30\%).

Positive slopes were observed for the PC1 axis for all biomes and all BA datasets, except for Cerrado (Table 2). These results were significant $(p<0.001)$ for all vegetation types, except for the Caatinga biome with GFED4 and MERIS FIRE_CCI BA datasets, which showed no significative values $(p<0.1)$. 

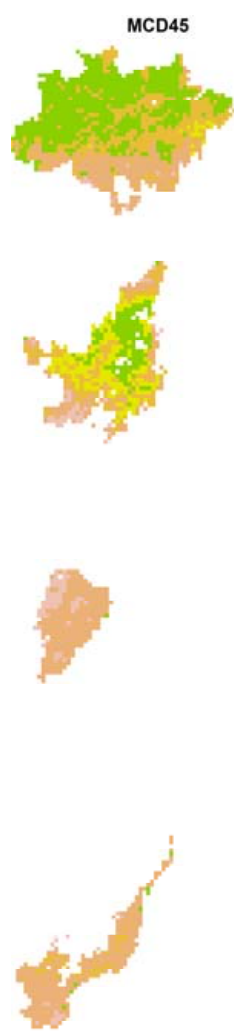
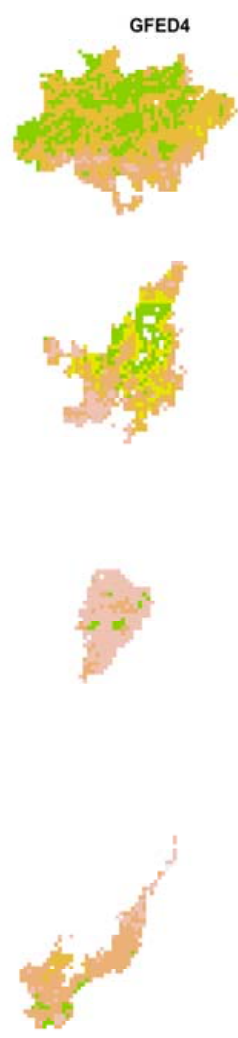
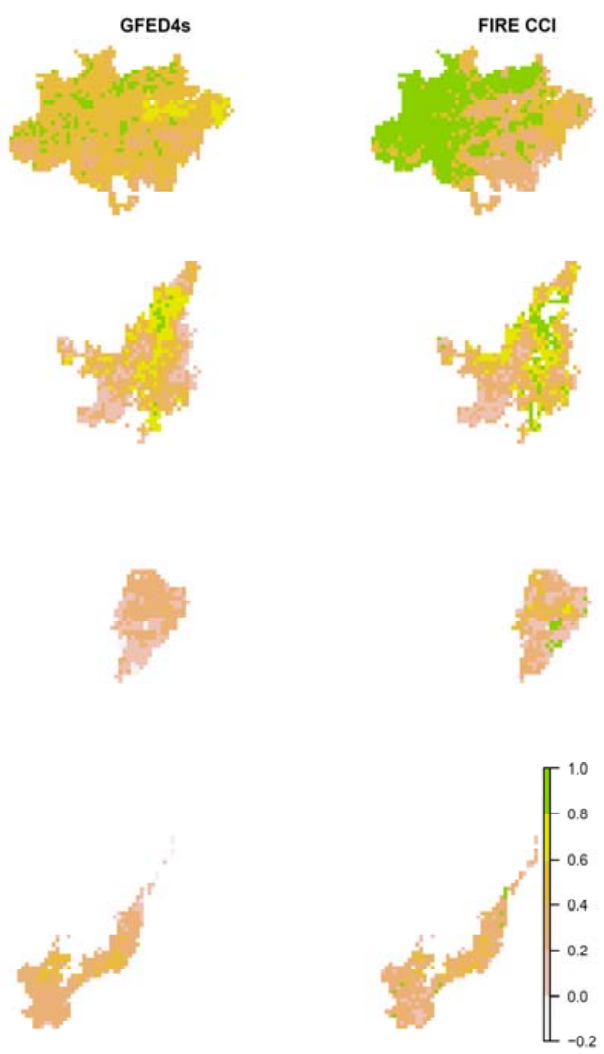

Figure 6. Probability maps of biome distribution (Amazonia, Cerrado, Caatinga and Forest Atlantic from top to bottom lines) for each BA dataset (MCD45, GFED4, GFED4s and MERIS FIRE_CCI ordered by column). These maps were obtained from a General Linear Regression Model based on the three main principal axes of the PCA performed on the FDI/BA relationship for each BA dataset.

Table 2. Linear coefficients (and its significances) of the general linear model for biome distribution as a function of PCA1 axis for each vegetation type over Brazil (Amazonia, Cerrado, Caatinga, and Atlantic Forest).

\begin{tabular}{ccccc}
\hline \multirow{2}{*}{$\begin{array}{c}\text { Burned Area } \\
\text { Datasets }\end{array}$} & Amazonia & Cerrado & Caatinga & Atlantic Forest \\
\cline { 2 - 4 } MCD45 & $0.10^{* * *}$ & $-0.41^{* * *}$ & $0.12^{* * *}$ & $0.15^{* * *}$ \\
GFED4 & $0.19^{* * *}$ & $-0.40^{* * *}$ & $0.08^{* * *}$ & $0.11^{* * *}$ \\
GFED4s & $0.06^{* * *}$ & $-0.22^{* * *}$ & $0.00^{\mathrm{NS}}$ & $0.11^{* * *}$ \\
MERIS FIRE_CCI & $0.20^{* * *}$ & $-0.44^{* * *}$ & $-0.02^{\mathrm{NS}}$ & $0.16^{* * *}$ \\
\hline
\end{tabular}

The linear coefficients are significatives in $p$-value $<0.001\left(^{* * *}\right)$ and no significant values for $p>0.1\left(^{\mathbf{N S}}\right)$.

Figure 7 finally displays the monthly fire season for each biome and BA product, showing the short fire season in Amazonia (Months 8 and 9), extending to Months 7 to 10 in the Cerrado, Months 7 to 11 in Caatinga, and Months 8 to10 in the Atlantic forest. When looking at the corresponding monthly drought pattern, we observe a similar temporal pattern between monthly BA and NI for the Cerrado, as well as good correlations between BA and Linacre_750, while the shorter fire season in Amazonia is only well correlated to NI, and poorly correlated to Linacre 100 indices simulating a too long drought period, thus supporting the PCA variable contributions. The Caatinga biome experiences the longest and latest fire season, not fully described by a peculiar drought index, as well as the Atlantic forest. 

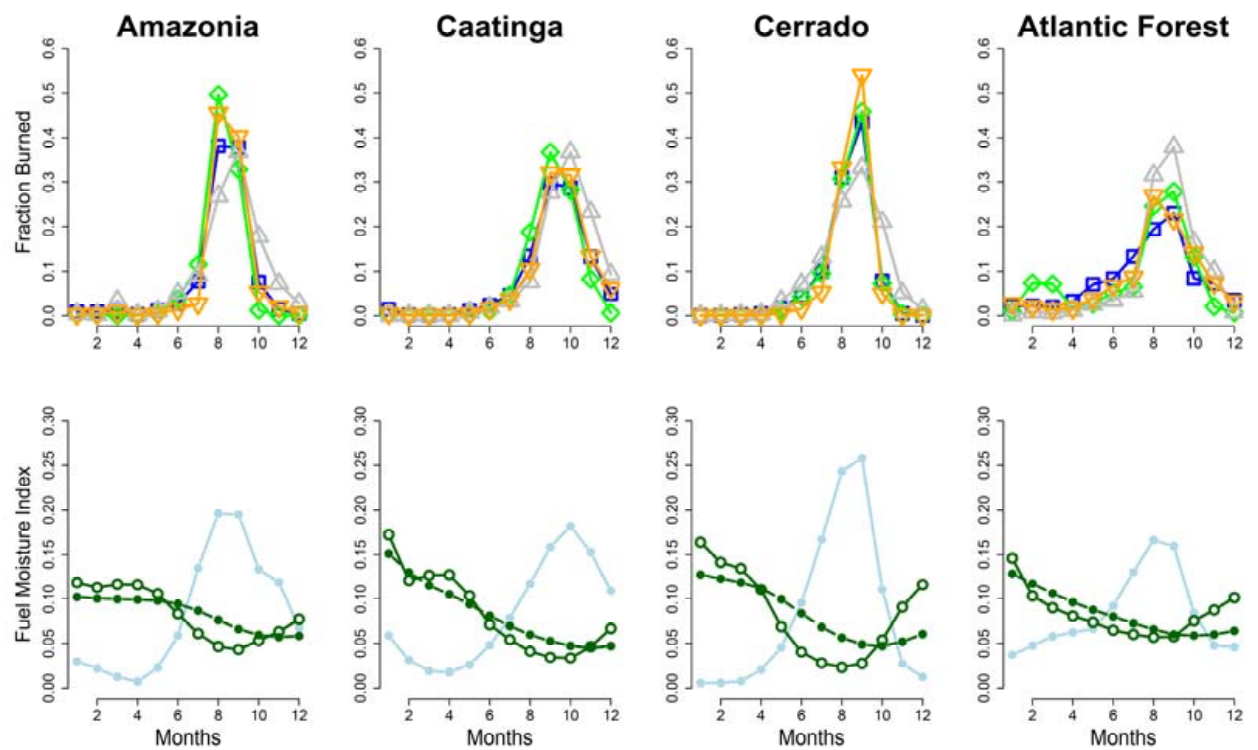

Figure 7. Monthly average distribution of standardized burned area (BA, above) and main meteorological fire danger indices (FDI, bellow) from 2002 to 2011. The BA represent MCD45 (green), GFED4 (dark blue), GFED4s (orange) and MERIS FIRE_CCI (gray). The main FDIs represented are Nesterov Index (NI, light blue), Linacre indices (dark green) to 100 (circles) and $750 \mathrm{~mm}$ (dashed circles) of soil field capacity.

\section{Discussion}

\subsection{Sensitivity of the Seasonal FDI/BA Relationship to BA Datasets}

Our analysis could show a good consistency of the seasonal FDI/BA relationship across different BA datasets although they are acknowledged to present potential discrepancies. The mean seasonal BA pattern for each biome of Brazil actually showed some discrepancies between datasets, with BA highest values being reached either in Month 8 or 9 in Amazonia according to the BA dataset under study.

We have to note here, however, the better correlations between monthly BA and FDIs when using GFED4s, the only BA dataset including small fires. This is mainly observed for the most fire-prone area Cerrado, but the gain in FDI/BA correlations when using GFED4s is even more important for the Amazonian biome. In this latter region, coefficients of determination obtained for most BA datasets are below 0.3 , while they reach values higher than 0.5 for GFED4s. This suggests that the fire regime in this not much fire-prone area (as a consequence of high air humidity and high soil water content along the year) is less correlated to drought by the conventional large fire datasets. The seasonal pattern of small fires would be more correlated to the drought pattern. This peculiar result then points out a potential bias in model developments based on BA observation from global remote sensing, and DGVMs/fire module benchmarking for this region when using the large fire dataset only. Recent studies actually pointed out the BA underestimation from these global products when compared to finer resolution Landsat-based remote sensing analysis $[63,66,67]$.

The use of FDIs to estimate the fire occurrence and fuel interaction has also been performed in different ecosystems in North America [68,69] and Europe [70-73]. However, these studies have used the alternative dataset of fire counts from satellites or field observations with few efforts in considering the sensitivity to BA datasets or the use of FDIs specific to represent the hydrological processes for each vegetation type [74].

\subsection{Biome Specific FDIs for the Seasonal Fire Pattern}

In Brazil, the official center of fire events previsions (CPTEC/INPE) uses a Meteorological Fire Danger Index (MFDI), based on daily meteorological conditions of temperature, relative humidity, 
cumulative precipitation and defoliation type to represent how vegetation is predisposed to burn on a given day [75,76]. This MFDI only evaluates air humidity to estimate the fire danger, considering that low values of relative humidity cause the dry out of vegetation and higher temperatures increase fuel ignition. Our approach testing FDIs related to soil moisture demonstrates their potentiality to be applied in fire danger assessments in Brazil to increase the feasibility of current fire events previsions.

Our results showed that FDIs could reproduce the seasonal constraint of climate/fuel moisture in the control of fire activity in the main Brazilian vegetation types, with a better correlation obtained for the dry and non-fuel-limited Cerrado ecosystem. Previous studies demonstrated that in wet tropical forests the fuel is always available for burning during the fire season due the high annual net productivity primary, so the fuel moisture conditions are more a limiting factor of fire activity [13]. In these ecosystems, the vegetation functioning and the subsequent adjustments of ecophysiological processes to drought tend to reduce the water loss. The air dryness associated to drought events or temperature heat waves have an additional important role in the climate regulation and soil water, which influences the drying of live and dead fuels [9]. Negative correlations have also been observed between soil moisture and fire activity in similar areas [13]. In this study, we also observed this negative correlation between soil moisture and fire activity in the Brazilian tropical forests. The soil moisture estimated by FDIs with high soil field capacity (i.e., $750 \mathrm{~mm}$ in the Linacre indices, mainly) and taking longer time to desiccate were more efficient to explain the seasonal fire pattern.

In contrast to these non-fuel-limited ecosystems, the driest ecosystems in Brazil (i.e., deserts and xeric shrublands) or seasonally dry (i.e., grasslands and shrublands) ecosystems can be fuel-limited so the primary production in the wet growing season preceding the fire season can affect the fuel resource able to burn [9]. Global and regional studies showed that in these ecosystems the increased soil moisture during the growing season have a positive correlation to fire activity, reflecting that the fuel accumulation process has a strongest constraint on fire occurrence [77]. This has not been tested here, but whatever the amount of biomass produced during the growing season, the seasonal pattern of fires is not affected, but only the final total burned area.

For Brazilian savannas (Cerrado), we observed that the most correlated FDIs were related to the precipitation effects on the top soil moisture mainly. Better correlations were obtained for NI, DC, and the Linacre index performed with a field capacity of $100 \mathrm{~mm}$ which represents the moisture content of the surface litter and fine fuels, dew-point deficit and the soil deficit for shallow soils (less than $200 \mathrm{~mm}$ of field capacity), respectively. As the main combustible fuel in the Cerrado consists of grasses and other ground-layer in their different physiognomies [78], our results suggest that in these ecosystems the seasonal fire activity increases with a rapid drying of grasses or herbaceous fuel. Good correlations between fire occurrence were also observed with FFDI index [79] in Cerrado and using FWI components system (i.e., FFMC) in others seasonally dry ecosystems [80-82]. In these regions, the fire is an essential component of vegetation dynamic and functioning. However, recent land use changes and increase of deforestation for land clearing, agriculture and cattle grazing can affect the interrelationship between fire-climate and vegetation by reducing fuel quantity and soil water budget. Generic indices as the FWI produced as a global database [83], might then not be equally suitable for the whole country with contrasted functional biomes. The SPEI index was finally poorly correlated to BA in our study area although showing good correlations in other biomes [84].

Although our analyses use coarse spatial resolution which limits the understanding of vegetation heterogeneity in the pixels, further analysis should explore the sensibility of FDIs on fire activity according to different vegetation composition of the Cerrado, with contrasted total fuel biomass and fuel moisture seasonal pattern [9]. The model used in this study weakly explained the fire occurrence in Caatinga. This region is typically dry and the low annual rainfall and high evapotranspiration rate might induce low climate responses. The burned area is low, so the remote sensing signal might be inaccurate or fuzzy, and the rare fire settings might be fully driven by human settings rather than climate. 
Our results demonstrate the better accuracy in most cases of the cumulative index that increases with no rain and decline when rains occur. Thus, we suggest the development of soil water balance models with biome-specific soil retention capacity. Availability of accurate aboveground biomass and land cover maps [85] will increase the integration of plant functions, community dynamics and fuel amount in further development for projecting fire danger.

\section{Conclusions Remarks}

In this study, we evaluated the sensitivity of the most used FDIs in describing the seasonal fire danger derived from remote sensing global products over Brazil. We showed that FDIs computed from empirical water balances considering a lower soil capacity are more correlated to the seasonal pattern of fire occurrence in the Cerrado biome with contrasted adjustments between the western (early drying) and eastern part (late drying), while the FFMC is more correlated to the fire seasonal pattern in Amazonia. For biomes with the lowest burned areas, the FDIs were better correlated when using GFED4s database, which includes small fires, while no major differences between the other BA products were observed. Thus, using a panel of drought indices, and different burned area databases provided useful information to understand the burned area seasonal pattern in the contrasted vegetation types covering Brazil. Generic standard fire weather index FWI [83] might then not be generic enough to be suitable across the contrasted biomes of the country.

Even though good correlations between FDIs and the seasonal pattern of burned areas were observed in our study, we cannot eliminate the human driver of fire setting, for which we have no information, but which can highly modify the seasonal fire pattern according to local fire practices [86]. Future studies should be carried out on longer time series and finer resolution such as the meso-scale pixel products from remote sensing (MERIS FIRE_CCI or MCD45) to consider local scale land use changes effects, which could bring more conclusive results on the ongoing trend in fire danger in Brazil.

Acknowledgments: This work was developed within the ESA Fire-Cci project, in the framework of the European Space Agency Climate Change Initiative program and the IRD/CNPq program. The Coordenação de Aperfeiçoamento de Pessoal Superior (CAPES, Brazil) provided a PhD grant to Joana Nogueira (BEX-1185-13-6 process).

Author Contributions: Joana M.P. Nogueira and Florent Mouillot designed the experiments; Joana M.P. Nogueira performed the analysis and led the study; Serge Rambal and João Paulo R.A.D. Barbosa contributed to the interpretation and discussion of results; and Joana M.P. Nogueira and Florent Mouillot wrote the manuscript.

Conflicts of Interest: The authors declare no conflict of interest.

\section{Appendix A}

Table A1. Daily meteorological variables obtained from climate CRU-NCEP dataset.

\begin{tabular}{|c|c|}
\hline Daily Meteorological Variables & Formula \\
\hline $\begin{array}{l}\text { Mean Incoming Short Wave Radiation }(\mathrm{Rg}, \\
\left.\mathrm{MJ} \cdot \mathrm{m}^{-2} \cdot \mathrm{day}^{-1}\right)\end{array}$ & - \\
\hline $\begin{array}{l}\text { Average annually }\left(\mathrm{P}, \mathrm{mm} \cdot \mathrm{day}^{-1}\right) \text { and total } \\
\text { daily (prec, mm) precipitation }\end{array}$ & $\mathrm{P}=$ mean $\sum$ prec \\
\hline Relative humidity (RH, \%) & $\begin{array}{l}\mathrm{RH}=100 \times \frac{\mathrm{ea}}{\mathrm{es}} \\
\mathrm{ea}=\frac{\mathrm{qair} \times \text { press }}{0.378 \times \text { qair }+0.622} ; \text { es }=6.112 \times \mathrm{e}^{\frac{17.67 \text { temp }}{\text { temp }+243.5}} \\
\text { ea }=\text { actual air vapour pressure }(\mathrm{kPa}) ; \mathrm{es}=\text { saturation air vapor pressure } \\
(\mathrm{kPa}) ; \text { qair }=\text { daily air specific humidity }\left(\mathrm{g} \cdot \mathrm{g}^{-1}\right) ; \text { temp = air temperature }(\mathrm{K}) ; \\
\text { press = air pressure }(\mathrm{Pa})\end{array}$ \\
\hline $\begin{array}{l}\text { Maximum (Tmax), minimum (Tmin), mean } \\
\text { (Tmean) and dew point (Tdew) } \\
\text { temperatures }\left({ }^{\circ} \mathrm{C}\right)\end{array}$ & 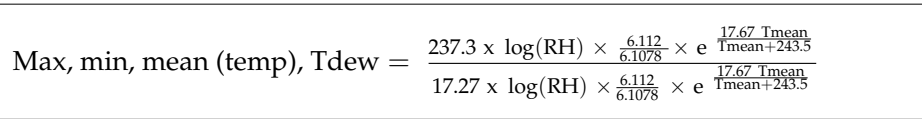 \\
\hline Wind speed $\left(\mathrm{w}, \mathrm{m} \cdot \mathrm{s}^{-1}\right)$ & $\begin{array}{l}\mathrm{w}=\sqrt{\text { uwind }^{2}+\mathrm{vwind}^{2}} \text { uwind and wind are horizontal and vertical wind } \\
\text { components }\left(\mathrm{m} \cdot \mathrm{s}^{-1}\right) \text {, respectively }\end{array}$ \\
\hline
\end{tabular}


Table A1. Cont.

\begin{tabular}{|c|c|}
\hline Daily Meteorological Variables & Formula \\
\hline & $\mathrm{ET}_{\mathrm{PM}}=\frac{\Delta(\mathrm{Rn}-\mathrm{G})+\rho \mathrm{a} \times \mathrm{cp} \times \frac{\mathrm{es}-\mathrm{ea}}{\mathrm{ra}}}{\Delta+\gamma\left(1+\frac{\mathrm{rs}}{\mathrm{ra}}\right)}$ \\
\hline $\begin{array}{l}\text { Evapotranspiration from Penman Monteith } \\
\text { model }\left(\mathrm{ETO}_{\mathrm{PM}}, \mathrm{mm} \cdot \mathrm{day}^{-1}\right)\end{array}$ & $\begin{array}{l}\mathrm{Rn}=\text { net radiation at the crop surface }\left(\mathrm{MJ} \cdot \mathrm{m}^{-2} \cdot \mathrm{day}^{-1}\right), \mathrm{G}=\text { soil heat flux } \\
\text { density }\left(\mathrm{MJ} \cdot \mathrm{m}^{-2} \cdot \text { day }\right. \\
-1), \rho \mathrm{a}=\text { mean air density at constant pressure } \\
\left(\mathrm{kg} \cdot \mathrm{m}^{-3}\right) ; \mathrm{cp}=\text { specific heat of the air }\left(\mathrm{MJ} \cdot \mathrm{kg}^{-1} \cdot{ }^{\circ} \mathrm{C}^{-1}\right) ; \mathrm{es}-\mathrm{ea}=\text { vapour } \\
\text { pressure deficit of the air }(\mathrm{kPa}) ; \Delta=\text { slope of the saturation vapour pressure } \\
\text { temperature relationship }\left(\mathrm{kPa} \cdot{ }^{\circ} \mathrm{C}^{-1}\right) ; \gamma=\text { psychrometric constant } \\
\left(\mathrm{kPa} \cdot{ }^{\circ} \mathrm{C}^{-1}\right) ; \mathrm{rs} \text { and ra }=\text { the bulk surface and aerodynamic resistances } \\
\left(\mathrm{s} \cdot \mathrm{m}^{-1}\right) \text {, respectively }\end{array}$ \\
\hline
\end{tabular}

Table A2. Overview of meteorological fire danger indices (FDI) and their respective formulas using variables from CRU-NCEP dataset described in Table A1.

\begin{tabular}{|c|c|c|}
\hline FDI & Formula $^{1}$ & References \\
\hline $\begin{array}{l}\text { McArthur Forest Fire } \\
\text { Danger Index (FFDI) }\end{array}$ & $\begin{array}{l}\mathrm{FFDI}_{t}=2 \mathrm{e}^{\left(-0.45+0.98 \ln \mathrm{DF}_{t}-0.0345 \times \mathrm{RH}_{t}-0.0338 \times \mathrm{Tmax}_{t}+0.0234 \mathrm{w}_{t}\right.} \\
\mathrm{DF}=\text { drought factor between } 0 \text { and } 10 \text { where, } \mathrm{DF}=\frac{0.191 \times(\mathrm{I}+104.0) \times \mathrm{N}^{1.5}}{\left(3.52 \times(\mathrm{N}+1)^{1.5}\right)+\mathrm{P}-1} \\
\mathrm{I}=\mathrm{KBDI} \text { index [20]; } \mathrm{N}=\mathrm{Number} \text { of days since last rain }(\text { considered here the days } \\
\text { with the prec values upper to } 2 \mathrm{~mm}[87]) ; \mathrm{RH}=\text { relative humidity }(\%) ; \mathrm{P}=\text { annually } \\
\text { average precipitation }\left(\mathrm{mm} \cdot \mathrm{day}^{-1}\right)\end{array}$ & [23] \\
\hline $\begin{array}{l}\text { Duff Moisture Code } \\
\text { (DMC) }\end{array}$ & $\begin{array}{l}\mathrm{DMC}=244.72-43.43 \ln (\mathrm{m}-20) \\
\mathrm{m}=\text { daily fuel moisture [19] for minimal prec values to } 1.5 \mathrm{~mm}\end{array}$ & \multirow{2}{*}{ [19] } \\
\hline Drought Code (DC) & $\begin{array}{l}\mathrm{DC}=400 \ln \frac{800}{\mathrm{Q}} \\
\mathrm{Q}=\mathrm{m} \text { equivalent }[19]\end{array}$ & \\
\hline Nesterov Index (NI) & $\begin{array}{l}\mathrm{NI}_{\mathrm{t}}=\sum_{t}^{\mathrm{N}} \mathrm{NI}_{t-1} \text { Tmean } \times \mathrm{D}_{t} \\
\mathrm{D}=\text { Tmean }- \text { Tdew } \\
\mathrm{N}=\text { Number of days since last rain; } \mathrm{D}=\text { dew point factor for maximal prec values to } \\
3 \mathrm{~mm} \cdot \text { day }^{-1} ; \text { Tmean }=\text { mean temperature }\left({ }^{\circ} \mathrm{C}\right) ; \mathrm{Tdew}=\mathrm{dew} \text { point temperature }\left({ }^{\circ} \mathrm{C}\right)\end{array}$ & [25] \\
\hline $\begin{array}{l}\text { Modified Nesterov } \\
\text { Index }(\mathrm{MNI})\end{array}$ & $\begin{array}{l}\mathrm{MNI}_{\mathrm{t}}=\mathrm{k} \times \mathrm{NI}_{\mathrm{t}-1} \\
\mathrm{k} \text { is a coefficient that gradually decreases between } 1 \text { (when no rainfall occurs) and } 0 \\
\text { (when daily rainfall is } 20 \mathrm{~mm} \text { or more) }\end{array}$ & [26] \\
\hline $\begin{array}{l}\text { Standardized } \\
\text { Precipitation- } \\
\text { Evapotranspiration } \\
\text { Index (SPEI) }\end{array}$ & $\begin{array}{l}\mathrm{SPEI}=\sum_{i=0}^{\mathrm{k}-1}\left(\mathrm{P}_{\mathrm{n}-\mathrm{i}}-\mathrm{PET}_{\mathrm{n}-\mathrm{i}}\right) \\
\mathrm{P}=\text { monthly precipitation }(\mathrm{mm}) ; \mathrm{i}=\text { time in months; } \mathrm{k}=\text { time window of the } \\
\text { aggregation for } 1,3,6,9,12,24 \text { and } 48 \text { months in this study; PET = actual } \\
\text { evapotranspiration rate, which was estimated in thisusing Penman-Monteith model } \\
(\mathrm{ET} 0 \mathrm{PM})[88,89]\end{array}$ & [29] \\
\hline $\begin{array}{l}\text { Linacre Index } \\
\text { (LINACRE) }\end{array}$ & $\begin{array}{l}\mathrm{LINACRE}_{t}=\frac{\mathrm{S}_{t}}{\mathrm{FC}} \\
\mathrm{S}_{t}=\text { soil water content }=\min \left(\mathrm{FC}, \mathrm{S}_{t-1}-\mathrm{ET}_{t}+\mathrm{R}_{t}\right) \\
\mathrm{AET}_{t}=\text { actual evapotranspiration }=\min \left(\mathrm{AET} \max \times\left(\frac{\mathrm{S}}{\mathrm{FC}}\right)^{2}, \mathrm{ET}_{\mathrm{PM}_{t}}\right) \\
\mathrm{FC}=\text { soil field capacity }(\mathrm{mm}) \text { of } 100,250,500 \text { and } 750 \mathrm{~mm} \text { for this study; } \mathrm{S}=\text { is total } \\
\text { saturated soil to initial time in first day of year; AET }=\text { actual evapotranspiration } \\
\left(\mathrm{mm} \cdot \text { day }^{-1}\right)\end{array}$ & {$[30]$} \\
\hline
\end{tabular}



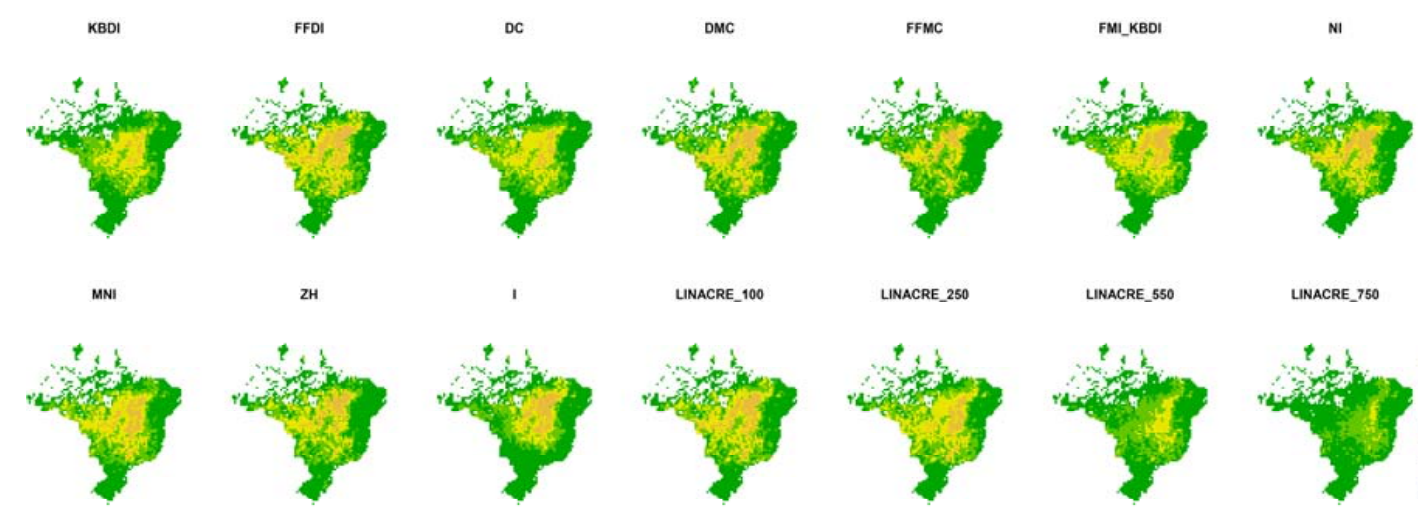

UINACRE_100

LINACRE_250

LINACRE_550

UINACRE_750
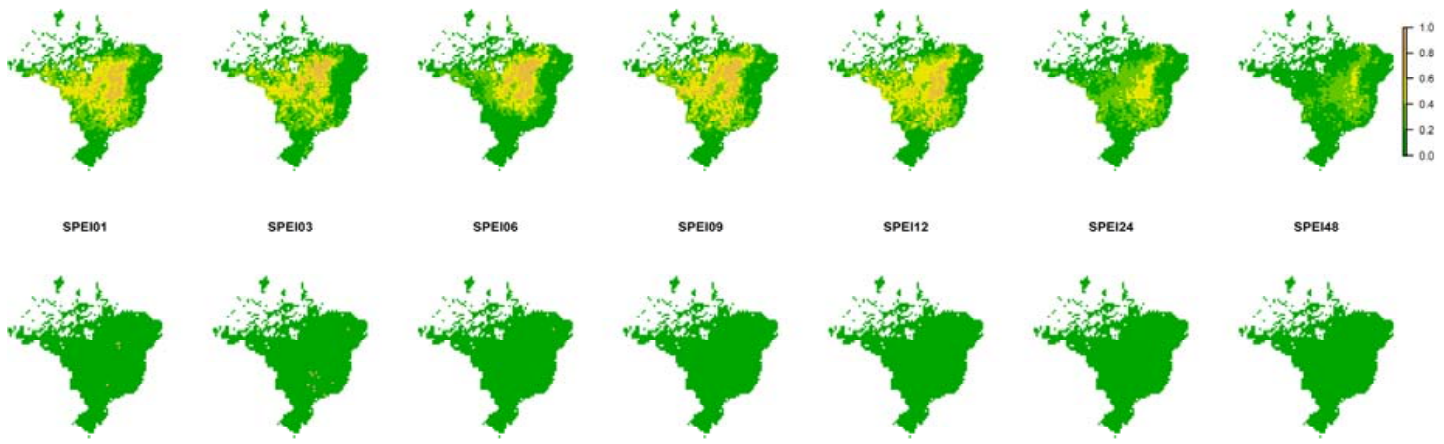

(a)

KBOI

oc
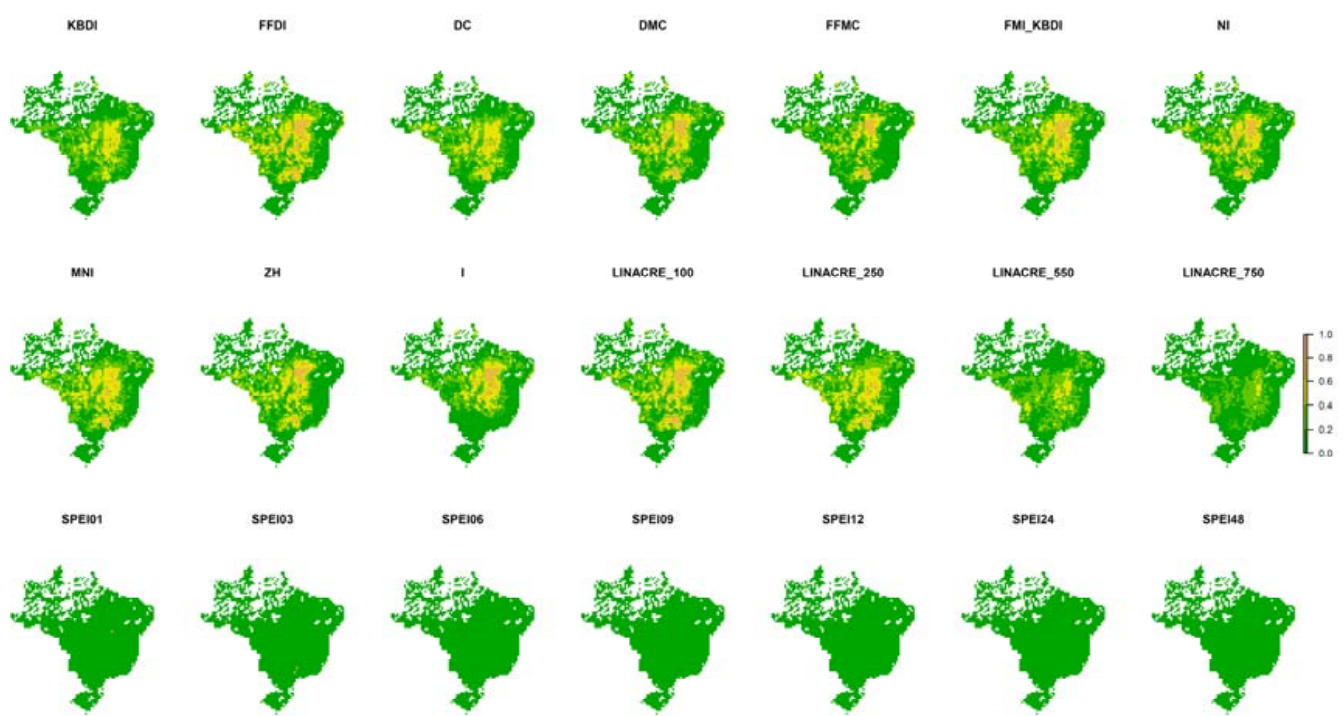

(b)
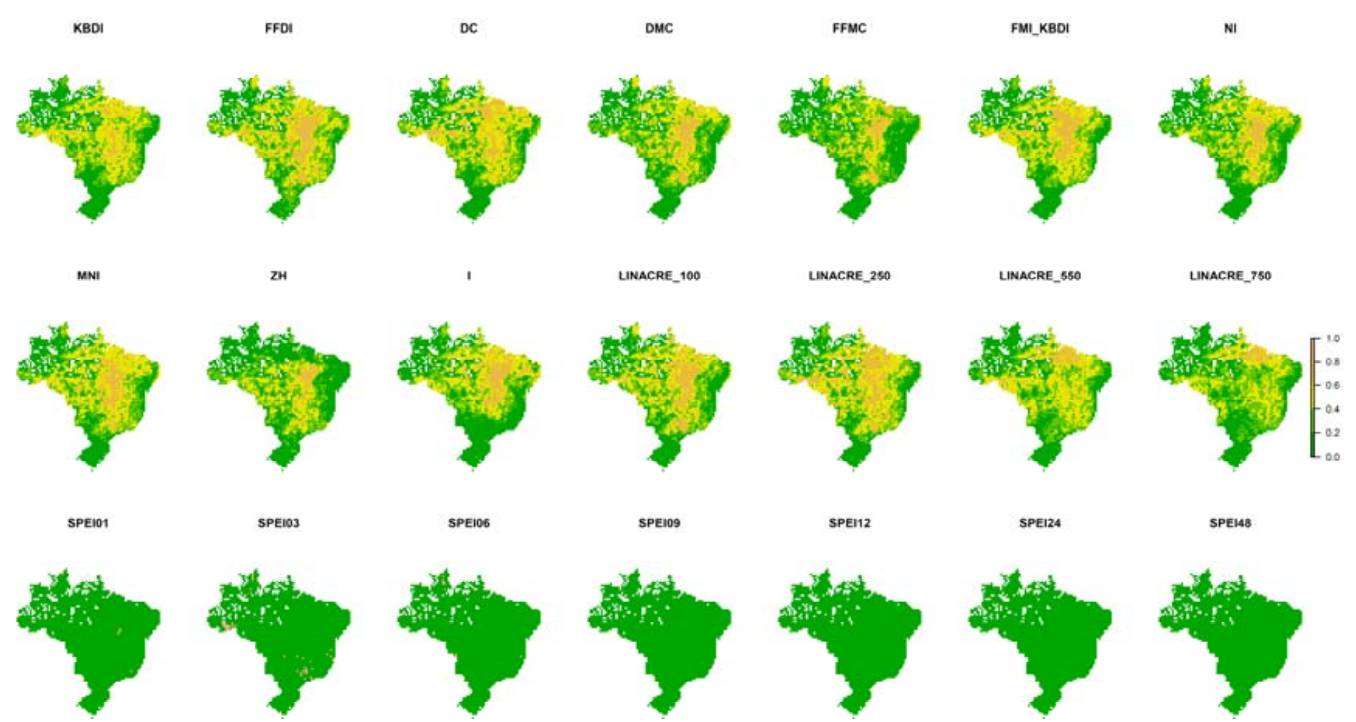

(c)

Figure A1. Cont. 


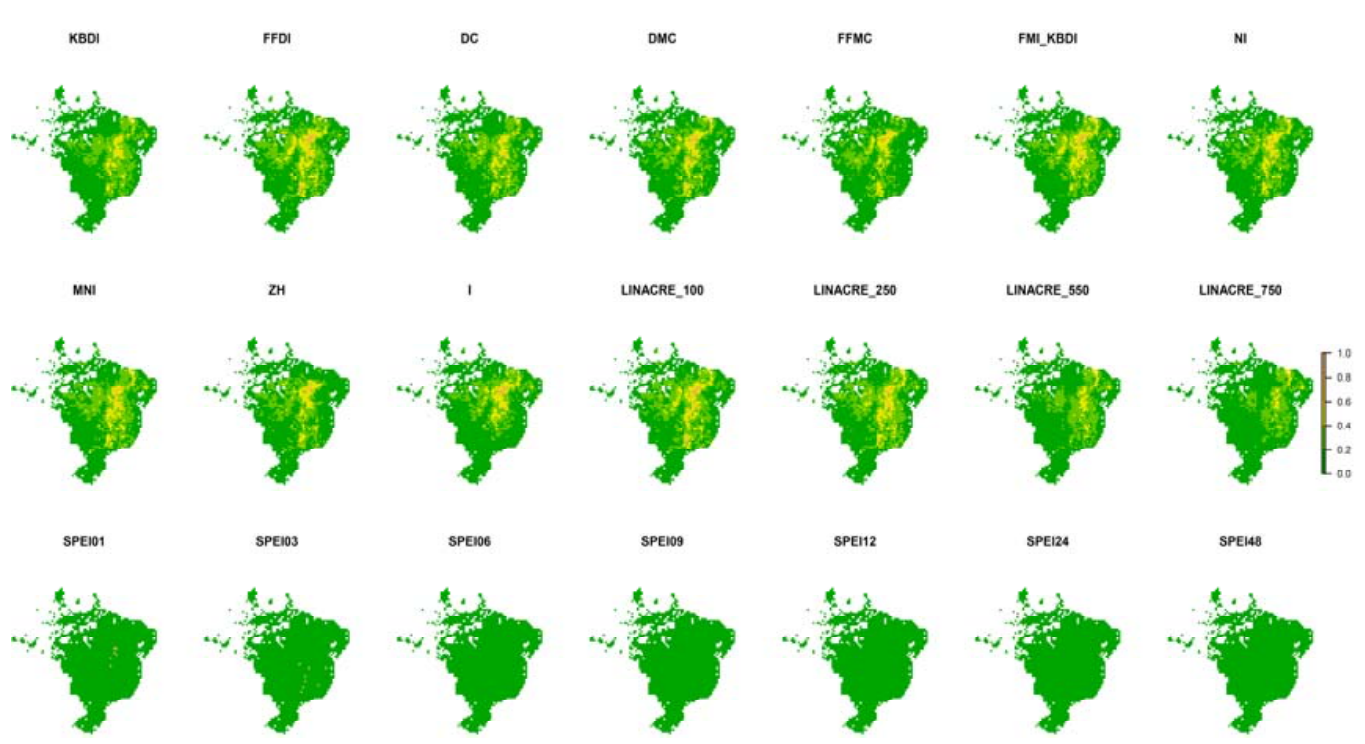

(d)

Figure A1. Coefficient of determination $\left(R^{2}\right)$ between burned area datasets ((a) MCD45A1; (b) GFED4; (c) GFED4s and (d) MERIS FIRE_CCI) and fire meteorological danger indices (FDI) computed from satellite climate dataset (CRUN-CEP). The FDI evaluated are McArthur index (FFDI), Duff Moisture Code (DMC), Drought Code (DC), Fine Fuel Moisture Code (FFMC), Swedish Angstrom index (I), Keetch-Bryam Drought Index (KBDI), Russian Nesterov Index (NI), Russian Modified NI (MNI), Zhdanko index (Zh), Australian Sharples Fire Weather Index (FMI_KBDI) and Linacre index with 100, 250, 550 and $750 \mathrm{~mm}$ of field soil capacity (Linacre_100 to 750).

\section{References}

1. Pausas, J.G.; Keeley, J.E. Evolutionary ecology of resprouting and seeding in fire-prone ecosystems. New Phytol. 2014, 204, 55-65. [CrossRef] [PubMed]

2. Bowman, D.M.J.S.; Balch, J.K.; Artaxo, P.; Bond, W.J.; Carlson, J.M.; Cochrane, M.A.; D'Antonio, C.M.; Defries, R.S.; Doyle, J.C.; Harrison, S.P.; et al. Fire in the earth system. Science 2009, 324, 481-484. [CrossRef] [PubMed]

3. Bowman, D.M.J.S.; Balch, J.; Artaxo, P.; Bond, W.J.; Cochrane, M.A.; D’Antonio, C.M.; Defries, R.; Johnston, F.H.; Keeley, J.E.; Krawchuk, M.A.; et al. The human dimension of fire regimes on earth. J. Biogeogr. 2011, 38, 2223-2236. [CrossRef] [PubMed]

4. IPCC-Intergovernamental Panel on Climate Change. Climate Change 2014: Impacts, Adaptation and Vulnerability; v2, cap.27; Cambridge University Press: Cambridge, UK, 2014. Available online: https: //www.ipcc.ch/report/ar5/wg2/ (accessed on 6 January 2016).

5. Pettinari, M.L.; Ottmar, R.D.; Prochard, S.J.; Andreu, A.G.; Chuvieco, E. Development and mapping of fuel characteristics and associated fire potentials for South America. Int. J. Wildland Fire 2014, 23, 643-654. [CrossRef]

6. Parisien, M.A.; Moritz, M.A. Environmental controls on the distribution of wildfire at multiple spatial scales. Ecol. Monogr. 2009, 79, 127-154. [CrossRef]

7. Hoffmann, W.A.; Jaconis, S.Y.; Mckinley, K.L.; Geiger, E.L.; Gotsch, S.G.; Franco, A.C. Fuels or microclimate? Understanding the drivers of fire feedbacks at savanna-forest boundaries. Austral Ecol. 2012, 37, 634-643. [CrossRef]

8. Ray, D.; Nepstad, D.; Moutinho, P. Micrometeorological and canopy controls of fire susceptibility in a forested Amazon landscape. Ecol. Appl. 2005, 15, 1664-1678. [CrossRef]

9. Stott, P. Combustion in tropical biomass fires: A critical review. Prog. Phys. Geogr. 2000, 24, 355-377. [CrossRef] 
10. Nepstad, D.C.; Lefebvre, P.A.; Silva, U.L.; Junior, T.J.; Schlesinger, P.; Solorzano, L.; Moutinho, P.R.S.; Ray, D.G. Amazon drought and its implications for forest flammability and tree growth: A basin-wide analysis. Glob. Chang. Biol. 2004, 10, 704-717. [CrossRef]

11. Chen, Y.; Morton, D.C.; Jin, Y.; Collatz, G.J.; Kasibhatla, P.S.; van der Werf, G.R.; DeFries, R.S.; Randerson, J.T. Long-term trends and interannual variability of forest, savanna and agricultural fires in South America. Carbon Manag. 2013, 4, 617-638. [CrossRef]

12. Meyn, A.; White, P.S.; Buhk, C.; Jentsch, A.; Carolina, N. Environmental drivers of large, infrequent wildfires: The emerging conceptual model. Prog. Phys. Geogr. 2007, 31, 287-312. [CrossRef]

13. Krawchuk, M.A.; Moritz, M.A. Constraints on global fire activity vary across a resource gradient. Ecology 2011, 92, 121-132. [CrossRef] [PubMed]

14. Bond, W.J. What limits trees in C4 grasslands and savannas? Annu. Rev. Ecol. Evol. Syst. 2008, 39, 641-659. [CrossRef]

15. Oliveira, P.T.S.; Wendland, E.; Nearing, M.A.; Scott, R.L.; Rosolem, R.; da Rocha, H.R. The water balance components of undisturbed tropical woodlands in the Brazilian cerrado. Hydrol. Earth Syst. Sci. 2015, 19, 2899-2910. [CrossRef]

16. Sano, E.E; Rosa, R.; Brito, J.L.; Ferreira, L.G. Land cover mapping of the tropical savanna region in Brazil. Environ. Monit. Assess. 2010, 166, 113-124. [CrossRef] [PubMed]

17. Chuvieco, E.; Aguado, I.; Jurdao, S.; Pettinari, M.L.; Yebra, M.; Salas, J.; Hantson, S.; de la Riva, J.; Ibarra, P.; Rodrigues, M.; et al. Integrating geospatial information into fire risk assessment. Int. J. Wildland Fire 2014, 23, 606-619. [CrossRef]

18. White, L.A.S.; White, B.L.A.; Ribeiro, G.T. Evaluation of Forest Fire Danger Indexes for Eucalypt Plantations in Bahia, Brazil. Int. J. For. Res. 2015, 2015, 1-6. [CrossRef]

19. Van Wagner, C.E.; Forest, P. Development and Structure of the Canadian Forest Fire Weather Index System; Forestry Technical Report; Canadian Forestry Service: Ottawa, ON, Canada, 1987. Available online: https: / / cfs.nrcan.gc.ca/publications/download-pdf/19927 (accessed on 20 May 2016).

20. Keetch, J.J.; Byram, G. A Drought Index for Forest Fire Control. Available online: https:/ /www.treesearch.fs. fed.us/pubs/40 (accessed on 13 July 2016).

21. German Weather Service (GWG). Available online: http://www.dwd.de (accessed on 12 January 2017).

22. San-Miguel-Ayanz, J.; Schulte, E.; Schmuck, G.; Camia, A.; Strobl, P.; Liberta, G.; Giovando, C.; Boca, R.; Sedano, F.; Kempeneers, P.; et al. Comprehensive Monitoring of Wildfires in Europe: The European Forest Fire Information System (EFFIS). Available online: https:/ / www.intechopen.com/books/approaches-tomanaging-disaster-assessing-hazards-emergencies-and-disaster-impacts / comprehensive-monitoring-ofwildfires-in-europe-the-european-forest-fire-information-system-effis- (accessed on 12 March 2017).

23. McArthur, A.G. Fire Behavior in Eucalypt Forests; Department of National Development, Forestry and Timber Bureau Leaflet: Canberra, Australia, 1967.

24. Willis, C.; Van Wilgen, B.; Tolhurst, K.; Everson, C.; D’Abreton, P.; Pero, L.; Fleming, G. Development of a National Fire Danger Rating System for South Africa; Department of Water Affairs and Forestry: Pretoria, South Africa, 2001. Available online: http://www.daff.gov.za/doaDev/sideMenu/ForestryWeb/dwaf/ cmsdocs/Elsa/Docs/Fire/Dev\%20of\%20Nat\%20Fire\%20Danger\%20Rating\%20System\%202001.pdf (accessed on 8 June 2016).

25. Nesterov, V.G. Combustibility of the Forest and Methods for Its Determination; USSR State Industry Press: Moscow, Russia, 1949; p. 76. (In Russian)

26. Venevsky, S.; Thonicke, K.; Sitch, S.; Cramer, W. Simulating fire regimes in human-dominated ecosystems: Iberian Peninsula case study. Glob. Chang. Biol. 2002, 8, 984-998. [CrossRef]

27. Zhdanko, V.A. Scientific basis of development of regional scales and their importance for forest fire management. In Contemporary Problems of Forest Protection from Fire and Firefighting; Melekhov, I.S., Ed.; Lesnaya Promyshlennost' Publ.: Moscow, Russia, 1965; pp. 53-89. (In Russian)

28. Sharples, J.J.; Mcrae, R.H.D.; Weber, R.O.; Gill, A.M. A simple index for assessing fire danger rating. Environ. Model. Softw. 2009, 24, 764-774. [CrossRef]

29. Vicente-Serrano, S.M.; Beguerai, S.; Lopez-Moreno, J.I.; Angulo-Martinez, M.; El Kenaway, A.M.A. New Global $0.5^{\circ}$ Gridded Dataset (1901-2006) of a Multiscalar Drought Index: Comparison with Current Drought Index Datasets Based on the Palmer Drought Severity Index. J. Hydrometeorol. 2010, 11, 1033-1041. [CrossRef] 
30. Linacre, E.T. A simpler empirical expression for actual evapotranspiration rates-A discussion. Agric. Meteorol. 1973, 11, 451-452. [CrossRef]

31. Mbow, C.; Kalifa, G.; Goze, B. Spectral indices and fire behavior simulation for fire risk assessment in savanna ecosystems. Remote Sens. Environ. 2004, 91. [CrossRef]

32. Mouillot, F.; Schultz, M.G.; Yue, C.; Cadule, P.; Tansey, K.; Ciais, P.; Chuvieco, E. Ten years of global burned area products from spaceborne remote sensing-A review: Analysis of user needs and recommendations for future developments. Int. J. Appl. Earth Obs. Geoinf. 2014, 26, 64-79. [CrossRef]

33. MMA-Ministério do Meio Ambiente. Available online: http://mma.gov.br/ (accessed on 5 June 2016).

34. Silvestrini, R.A.; Soares-Filho, B.S.; Nepstad, D.; Coe, M.; Rodrigues, H.; Assunção, R. Simulating Fire Regimes in the Amazon in Response to Climate Change and Deforestation. Ecol. Appl. 2011, 21, 1573-1590. [CrossRef] [PubMed]

35. Villar, J.C.E.; Ronchail, J.; Guyot, J.L.; Cochonneau, G.; Naziano, F.; Lavado, W.; De Oliveira, E.; Pombosa, R.; Vauchel, P. Spatio-temporal rainfall variability in the Amazon basin countries (Brazil, Peru, Bolivia, Colombia, and Ecuador). Int. J. Climatol. 2009, 29, 1574-1594. [CrossRef]

36. Joly, C.A.; Metzger, J.P.; Tabarelli, M. Experiences from the Brazilian Atlantic Forest: Ecological findings and conservation initiatives. New Phytol. 2014, 204, 459-473. [CrossRef] [PubMed]

37. Mixtry, J. Fire in the cerrado (savannas) of Brazil: An ecological review. Prog. Phys. Geogr. 1998, 22. [CrossRef]

38. Goldammer, J.G. Fire in the Tropical Biota: Ecosystem Processes and Global Challenges; Ecological Studies 84; Springer: Berlin/Heidelberg, Germany; New York, NY, USA, 1990; p. 497.

39. Ottmar, R.D.; Sandberg, D.V.; Riccardi, C.L.; Prichard, S.J. An overview of the Fuel Characteristic Classification System-Quantifying, classifying, and creating fuelbeds for resource planning. Can. J. For. Res. 2007, 37, 2383-2393. [CrossRef]

40. Bicheron, P.; Defourny, P.; Brockmann, C.; Schouten, L.; Vancutsem, C.; Huc, M.; Bontemps, S.; Leroy, M.; Achard, F.; Herold, M.; et al. GLOBCOVER: Products Description and Validation Report; MEDIAS-France/POSTEL: Toulouse, France, 2008; p. 47.

41. Olson, D.M.; Dinerstein, E.; Wikramanayake, E.D.; Burgess, N.D.; Powell, G.V.N.; Underwood, E.C.; D'Amico, J.A.; Itoua, I.; Strand, H.E.; Morrison, J.C.; et al. Terrestrial Ecoregions of the World: A New Map of Life on Earth. Bioscience 2001, 51, 933-938. [CrossRef]

42. CRU-NCEP—Climatic Research Unit (CRU)—National Centers for Environmental Prediction (NCEP). Available online: http://dods.extra.cea.fr/data/p529viov/cruncep/ (accessed on 3 May 2016).

43. Harris, I.; Jones, P.D. CRU TS3.22: Climatic Research Unit (CRU) Time-Series (TS) Version 3.22 of High Resolution Gridded Data of Month-by-Month Variation in Climate (January 1901-December 2013). Available online: http://catalogue.ceda.ac.uk/uuid/4a6d071383976a5fb24b5b42e28cf28f (accessed on 17 September 2016).

44. Kalnay, E.; Kanamitsu, M.; Kistler, R.; Collins, W.; Deaven, D.; Gandin, L.; Iredell, M.; Saha, S.; White, G.; Woollen, J.; et al. The NCEP/NCAR 40-year reanalysis project. Bull. Am. Meteorol. Soc. 1996, 77, 437-470. [CrossRef]

45. Awange, J.L.; Mpelasoka, F.; Goncalves, R.M. When every drop counts: Analysis of droughts in Brazil for the 1901-2013 period. Sci. Total Environ. 2016, 566, 1472-1488. [CrossRef] [PubMed]

46. Dolling, K.; Chu, P.S.; Fujioka, F. A climatological study of the Keetch/Byram drought index and fire activity in the Hawaïan islands. Agric. For. Meteorol. 2005, 133, 17-27. [CrossRef]

47. Dowdy, A.J.; Mills, G.A.; Finkele, K.; Groot, W. Australian Fire Weather as Represented by the McArthur Forest Fire Danger Index and the Canadian Forest Fire Weather Index. CAWCR Technical Report 10. Available online: http://www.bushfirecrc.com/sites/default/files/managed/resource/ctr_010_0.pdf (accessed on 17 September 2016).

48. Casanueva, A.; Frías, M.D.; Herrera, S.; San-Martín, D.; Zaninovic, K.; Gutiérrez, J.M. Statistical downscaling of climate impact indices: Testing the direct approach. Clim. Chang. 2014, 127, 547-560. [CrossRef]

49. Viney, N.R. A review of fine fuel moisture modelling. Int. J. Wildland Fire 1991, 1, 215-234. [CrossRef]

50. Vicente-Serrano, S.M.; Gouveia, C.; Camarero, J.J.; Begueria, S.; Trigo, R.; Lopez-Moreno, J.I.; Azorin-Molina, C.; Pasho, E.; Lorenzo-Lacruz, J.; Revuelto, J.; et al. Response of vegetation to drought time scales across global biomes. Proc. Natl. Acad. Sci. USA 2013, 110, 52-57. [CrossRef] [PubMed]

51. Global Standard Precipitation Evapotranspiration Index Database (SPEIbase) Version 2.4. Available online: http:/ / sac.csic.es/spei/database.html (accessed on 22 September 2016). 
52. Giambelluca, T.W.; Scholz, F.G.; Bucci, S.J.; Meinzer, F.C.; Goldstein, G.; Hoffmann, W.A.; Franco, A.C.; Buchert, M.P. Evapotranspiration and energy balance of Brazilian savannas with constrasting tree density. Agric. For. Meteorol. 2009, 149, 1365-1376. [CrossRef]

53. Da Rocha, H.R.; Manzi, A.O.; Cabral, O.M.; Miller, S.D.; Goulden, M.L.; Saleska, S.R.; Coupe, N.R.; Wofsy, S.C.; Borma, L.S.; Artaxo, P.; et al. Patterns of water and heat flux across a biome gradient from tropical forest to savanna in Brazil. J. Geophys. Res. Biogeosci. 2009, 114. [CrossRef]

54. Wang, X.; Cantin, A.; Parisien, M.A.; Wotton, M.; Anderson, K.; Moore, B.; Flannigan, M. cffdrs: Canadian Forest Fire Danger Rating System, R Package Version 1.7.3. Available online: https:/ /CRAN.R-project.org/ package $=$ cffdrs (accessed on 10 July 2016).

55. R CRAN Program-Comprehensive R Archive Network. Available online: https:/ /CRAN.R-project.org/ (accessed on 21 February 2016).

56. Begueria, S.; Vicente-Serrano, S.M.; Angulo, M. A multi-scalar global drought data set: The SPEIbase: A new gridded product for the analysis of drought variability and impacts. Bull. Am. Meteorol. Soc. 2010, 91, 1351-1354. [CrossRef]

57. Roy, D.P.; Boschetti, L.; Justice, C.O.; Ju, J. The collection 5 MODIS burned area product—Global evaluation by comparison with the MODIS active fire product. Remote Sens. Environ. 2008, 112, 3690-3707. [CrossRef]

58. Giglio, L.; Randerson, J.T.; Van Der Werf, G.R. Analysis of daily, monthly, and annual burned area using the fourth-generation global fire emissions database (gfed4). J. Geophys. Res. Biogeosci. 2013, 118, 3690-3707. [CrossRef]

59. Randerson, J.T.; Chen, Y.; Van Der Werf, G.R.; Rogers, B.M.; Morton, D.C. Global burned area and biomass burning emissions from small fires. J. Geophys. Res. Biogeosci. 2012, 117. [CrossRef]

60. Chuvieco, E.; Yue, C.; Heil, A.; Mouillot, F.; Alonso-Canas, I.; Padilla, M.; Pereira, J.M.; Oom, D.; Tansey, K. A new global burned area product for climate assessment of fire impacts. Glob. Ecol. Biogeogr. 2016, 25, 619-629. [CrossRef]

61. ESA Fire Cci project-European Agence Spatial Climate Change Iniative. Available online: http://esa-firecci.org/ (accessed on 2 March 2017).

62. Alonso-Canas, I.; Chuvieco, E. Global Burned Area Mapping from ENVISAT-MERIS data. Remote Sens. Environ. 2015, 163, 140-152. [CrossRef]

63. Cardozo, F.D.; Pereira, G.; Shimabukuro, Y.E.; Moraes, E.C. Analysis and assessment of the spatial and temporal distribution of burned areas in the Amazon Forest. Remote Sens. 2014, 6, 8002-8025. [CrossRef]

64. MCD45A1 Burned Area Dataset Download. Available online: https://lpdaac.usgs.gov/ (accessed on 14 August 2016).

65. GFED4 and GFED 4s Burned Area Datasets Download. Available online: http://www.globalfiredata.org/ (accessed on 24 November 2016).

66. Libonati, R.; DaCamara, C.C.; Setzer, A.W.; Morelli, F.; Melchiori, A.E. An algorithm for burned area detection in the Brazilian Cerrado using 4 mm MODIS imagery. Remote Sens. 2015, 7, 15782-15803. [CrossRef]

67. Nogueira, J.M.P.; Ruffault, J.; Chuvieco, E.; Mouillot, F. Can we go beyond burned area in the assessment of global remote sensing products with fire patch metrics? Remote Sens. 2017, 9, 7. [CrossRef]

68. Abatzoglou, J.T.; Kolden, A.C. Relationships between climate and macroscale area burned in the western United States. Int. J. Wildland Fire 2013, 22, 1003-1020. [CrossRef]

69. Addington, N.R.; Hudson, J.S.; Hiers, J.K.; Hurteau, D.M.; Hutchersonn, F.T.; Matusick, G.; Parker, M.J. Relationships among wildfire, prescribed fire, and drought in a fire-prone landscape in the south-eastern United States. Int. J. Wildland Fire 2015, 24, 778-783. [CrossRef]

70. Padilla, M.; Vega-García, C. On the comparative importance of fire danger rating indices and their integration with spatial and temporal variables for predicting daily human-caused fire occurrences in Spain. Int. J. Wildland Fire 2011, 20, 46-58. [CrossRef]

71. Holsten, A.; Dominic, A.R.; Costa, L.; Kropp, J.P. Evaluation of the performance of meteorological forest fire indices for German federal states. For. Ecol. Manag. 2013, 287, 123-131. [CrossRef]

72. Arpaci, A.; Eastaugh, C.S.; Vacik, H. Selecting the best performing fire weather indices for Austrian ecoregions. Theor. Appl. Climatol. 2013, 114, 393-406. [CrossRef] [PubMed]

73. De Angelis, A.; Ricotta, C.; Conedera, M.; Pezzatti, G.B. Modelling the Meteorological Forest Fire Niche in Heterogeneous Pyrologic Conditions. PLoS ONE 2015, 10, e0116875. [CrossRef] [PubMed] 
74. Williams, A.P.; Seager, R.; Macalady, A.K.; Berkelhammer, M.; Crimmins, M.A.; Swetnam, T.W.; Trugman, A.T.; Buenning, N.; Noone, D.; McDowell, N.G.; et al. Correlations between components of the water balance and burned area reveal new insights for predicting forest fire area in the southwest United States. Int. J. Wildland Fire 2015, 24, 14-26. [CrossRef]

75. Silva, P.; Bastos, A.; DaCamara, C.C.; Libonati, R. Future Projections of Fire Occurrence in Brazil Using EC-Earth Climate Model. Revista Brasileira de Meteorologia 2016, 31, 288-297. [CrossRef]

76. Sismanoglu, R.A.; Setzer, A.W. Avaliação Regional dos Prognósticos do Risco de fogo Semanal do CPTEC Aplicando o Modelo "ETA" e Dados Observacionais na América do Sul; XIII; Congresso Brasileiro de Meteorologia, SBMET: Fortaleza-CE, Brazil, 2004.

77. Archibald, S.; Roy, D.P.; Van Wilgen, B.W.; Scholes, R.J. What limits fire? An examination of drivers of burnt area in Southern Africa. Glob. Chang. Biol. 2009, 15, 613-630. [CrossRef]

78. Pivello, V.R. The Use of Fire in the Cerrado and Amazonian Rainforests of Brazil: Past and Present. Fire Ecol. 2011, 7, 24-39. [CrossRef]

79. Hoffmann, W.A.; Moreira, A.G. The role of fire in population dynamics of woody plants. In The Cerrados of Brazil: Ecology and Natural History of a Neotropical Savanna; Oliveira, P.S., Marquis, R.J., Eds.; Columbia University Press: New York, NY, USA, 2002; pp. 159-177.

80. Pellizzaro, G.; Duce, P.; Ventura, A.; Zara, P. Seasonal variations of live moisture content and ignitability in shrubs of the Mediterranean Basin. Int. J. Wildland Fire 2007, 16, 633-641. [CrossRef]

81. Dimitrakopoulos, A.P.; Bemmerzouk, A.M.; Mitsopoulos, I.D. Evaluation of the Canadian fire weather index system in an eastern Mediterranean environment. Meteorol. Appl. 2011, 18, 83-93. [CrossRef]

82. Pausas, J.G.; Fernández-Muñoz, S. Fire regime changes in the Western Mediterranean Basin: From fuel-limited to drought-driven fire regime. Clim. Chang. 2012, 110, 215-226. [CrossRef]

83. Field, R.D.; Spessa, A.C.; Aziz, N.A.; Camia, A.; Cantin, A.; Carr, R.; de Groot, W.J.; Dowdy, A.J.; Flannigan, M.D.; Manomaiphiboon, K.; et al. Development of a global fire weather database. Nat. Hazards Earth Syst. Sci. 2015, 6, 1407-1423. [CrossRef]

84. Turco, M.; von Hardenberg, J.; AghaKouchak, A.; Llasat, M.C.; Provenzale, A.; Trigo, R.M. On the key role of droughts in the dynamics of summer fires in Mediterraneean Europe. Sci. Rep. 2017, 7, 81.

85. Carreiras, J.M.; Jones, J.; Lucas, R.M.; Shimabukuro, Y.E. Mapping major land cover types and retrieving the age of secondary forests in the Brazilian Amazon by combining single-date optical and radar remote sensing data. Remote Sens. Environ. 2017, 194, 16-32. [CrossRef]

86. Magi, B.I.; Rabin, S.; Shevliakova, E.; Pacala, S. Separating agricultural and non-agricultural fire seasonality at regional scales. Biogeosciences 2012, 9, 3003-3012. [CrossRef]

87. Finkele, K.; Mills, G.A; Beard, G.; Jones, D.A. National gridded drought factors and comparison of two soil moisture deficit formulations used in prediction of Forest Fire Danger Index in Australia. Aust. Meteorol. Mag. 2006, 55, 183-197.

88. Monteith, J.L. Evaporation and environment. Symp. Soc. Exp. Biol. 1965, 19, 205-224. [PubMed]

89. Penman, H.L. Natural evaporation from open water, bare soil and grass. Proc. R. Soc. Lond. A 1948, 194, 120-145. Available online: http:/ /eprints.icrisat.ac.in/8740/1/RP-09537.pdf (accessed on 18 April 2016). [CrossRef]

(c) 2017 by the authors. Licensee MDPI, Basel, Switzerland. This article is an open access article distributed under the terms and conditions of the Creative Commons Attribution (CC BY) license (http://creativecommons.org/licenses/by/4.0/). 